\title{
Data report: permeability and microfabric of core samples from IODP Expedition 348, Hole C0002P, Nankai Trough accretionary prism ${ }^{1}$
}

\author{
Chen Song $^{2}$ and Michael B. Underwood ${ }^{3}$
}

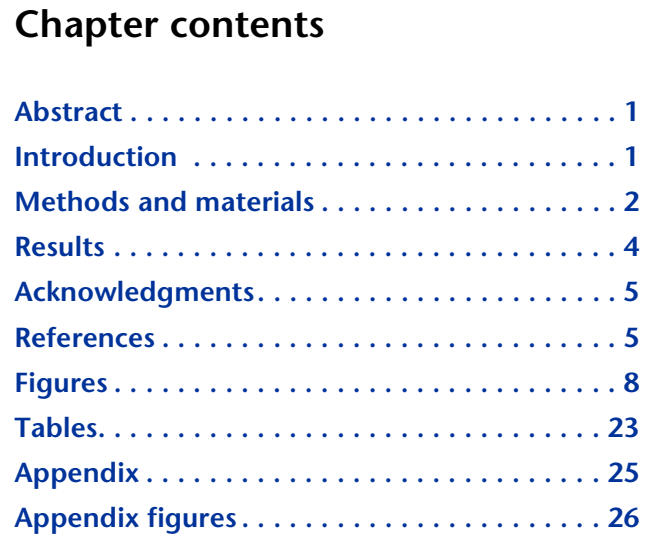

${ }^{1}$ Song, C., and Underwood, M.B., 2017. Data report: permeability and microfabric of core samples from IODP Expedition 348, Hole C0002P, Nankai Trough accretionary prism. In Tobin, $\mathrm{H}$., Hirose, T., Saffer, D., Toczko, S., Maeda, L., Kubo, Y., and the Expedition 348 Scientists, Proceedings of the Integrated Ocean Drilling Program, 348: College Station, TX (Integrated Ocean Drilling Program).

doi:10.2204/iodp.proc.348.201.2017

${ }^{2}$ Department of Geological Sciences, University of Missouri, Columbia MO 65211, USA.

${ }^{3}$ Department of Earth and Environmental Science, New Mexico Institute of Mining and Technology,

Socorro NM 87801, USA.

UnderwoodM@missouri.edu

\section{Abstract}

This report documents the results of constant-flow permeability tests in the vertical (along core) direction administered at effective isotropic confining stresses of $0.28 \mathrm{MPa}(40 \mathrm{psi})$ and $0.55 \mathrm{MPa}$ (80 psi). Specimens from the Nankai accretionary prism were collected from Hole C0002P of the Integrated Ocean Drilling Program. Beds dip at steep angles (typically $80^{\circ}$ or more) throughout the cored interval (2174.98-2209.64 meters below seafloor). We tested specimens that consist of indurated clayey siltstone and medium to coarse siltstone. Environmental scanning electron microscopy shows that grain fabric is random and does not vary significantly among the specimens tested. Hydraulic conductivity values range from $3.83 \times 10^{-9}$ to $2.68 \times 10^{-8} \mathrm{~cm} / \mathrm{s}$. Intrinsic permeability values range from $3.80 \times 10^{-18}$ to $2.66 \times 10^{-17} \mathrm{~m}^{2}$.

\section{Introduction}

The primary objective of Integrated Ocean Drilling Program (IODP) Expedition 348 was to characterize the variations of lithology and structure at intermediate depths of the Nankai Trough accretionary prism (offshore southwest Japan). Site C0002 (Fig. F1) is located on the upper plate of the subduction zone above the seismogenic (presumably locked) portion of the plate boundary thrust system (see the "Expedition 348 summary" chapter [Tobin et al., 2015a]). The long-term goal of deeper drilling at this site is to cross the megasplay at seismogenic depths where coseismic slip occurred during the 1944 Tonankai earthquake (Ichinose et al., 2003). During Expedition 348, IODP collected a full suite of logging-while-drilling data, cuttings at $\sim 5 \mathrm{~m}$ intervals, and cores over a $55.5 \mathrm{~m}$ interval from 2163 to 2218.5 meters below seafloor (mbsf). The cores are the deepest ever recovered from an active accretionary prism.

Intrinsic permeability $(k)$ and hydraulic conductivity $(K)$ values for natural clay-rich sediment and sedimentary rock (e.g., Neuzil, 1994; Aplin et al., 2006; Gamage et al., 2011) typically span several orders of magnitude. That natural variability exists because their hydrogeological properties depend on many factors, some of which are inherited from the time of mud deposition. Grain size and shape, sorting, particle orientation, surface charges on clay particles, and microfabric are important, as are the superimposed 
effects of burial diagenesis (e.g., Moon and Hurst, 1984; Bennett et al., 1989).

The cores from Hole C0002P contain numerous layers and irregular lenses of fine sand- and siltstone, with thicknesses ranging from laminae (millimeter scale) to $\sim 20 \mathrm{~cm}$. Those coarser textures should increase values of permeability. Furthermore, the strata dip steeply over the cored interval, typically at angles $>80^{\circ}$ (see the "Expedition 348 summary" chapter [Tobin et al., 2015a]). Those orientations should alter the anisotropy of permeability (i.e., horizontal versus vertical) relative to a normally compacted sedimentary basin. Our study contributes new data to the transect-wide Nankai Trough Seismogenic Zone Experiment (NanTroSEIZE), thereby allowing for hydrogeological comparisons among samples from the subduction inputs, Kumano forearc basin, the frontal accretionary prism, and the deeper (inner) accretionary prism (Dugan and Daigle, 2011; Ekinci et al., 2011; Guo et al., 2011; Saffer et al., 2011; Hüpers and Kopf, 2012; Rowe et al., 2012; Yue et al., 2012; Dugan and Zhao, 2013; Screaton et al., 2013; Daigle and Dugan, 2014; Guo and Underwood, 2014).

\section{Methods and materials}

\section{Sampling and sample handling}

This project was allocated four whole-round (WR) specimens for constant-flow permeability tests. The objective was to test interbeds of clayey siltstone and fine sand to siltstone turbidites. The samples are from lithostratigraphic Unit V (accreted trench or Shikoku Basin deposits) over a depth of 2174.98 to 2209.64 mbsf (Fig. F2). The WR samples were capped and taped in their plastic core liners on board the D/ V Chikyu, sealed with wet sponges in aluminum vacuum bags to prevent moisture loss, and stored at $\sim 4^{\circ} \mathrm{C}$ until immediately prior to trimming. The specimens we tested are texturally and compositionally heterogeneous, with siltstone laminae and black bands of pyrite. Steep bedding dips are also obvious in the specimens (Fig. F3).

The specimens were indurated and easy to extract without cutting the liners open. Unfortunately, one section (348-C0002P-2R-2) fell into pieces, so only three were tested in the vertical (along core) direction. In addition, the WR intervals were too small to allow trimming of companion specimens in the horizontal (cross core) direction, thereby precluding an assessment of the anisotropy of permeability. Each cylindrical specimen was trimmed along the sides, top, and bottom using a razor blade and knife. Their lengths after trimming ranged from 3.6 to $7.8 \mathrm{~cm}$ and averaged $5.46 \mathrm{~cm}$, as measured by caliper to a resolution of $0.02 \mathrm{~mm}$. The diameters were 3.8 to 4.5 $\mathrm{cm}$ and averaged $4.0 \mathrm{~cm}$.

For most samples, we calculated values of initial (pretest) and post-test porosity from measurements of gravimetric water content (Table T1). This was done by oven-drying the trimmings at $105^{\circ} \mathrm{C}$ in accordance with shipboard protocols (see the "Methods" chapter [Tobin et al., 2015b]) and by assuming 100\% pore water saturation. However, the material dried out quickly during the trimming, so some of the values of pretest porosity may be inaccurate. Comparable values of grain density and porosity were imported from shipboard measurements of the closest adjacent specimen (see the "Site C0002" chapter [Tobin et al., 2015c]). A correction for pore water salt content was applied using:

$$
W_{\mathrm{c}}=\left(M_{\mathrm{t}}-M_{\mathrm{d}}\right) /\left(M_{\mathrm{d}}-r M_{\mathrm{t}}\right),
$$

where

$$
\begin{aligned}
& W_{\mathrm{c}}=\text { corrected dry weight } \\
& M_{\mathrm{t}}=\text { total mass of saturated specimen, } \\
& M_{\mathrm{d}}=\text { mass of dried specimen, and } \\
& r \quad=\text { salinity (permil). }
\end{aligned}
$$

For salt corrections on pretest trimmings, we assumed an average interstitial salinity value of $35 \%$. For post-test trimmings, we assumed a salinity value of $25 \%$ to approximate the simulated seawater that was used to saturate specimens.

\section{Constant-flow apparatus}

Yue et al. (2012) provided a thorough description of the instrumentation and procedures for testing permeability at the University of Missouri (USA). To summarize, the system consists of an acrylic confining cell, porous stones between the specimen and end caps, a constant-flow syringe pump, one differential pressure transducer to measure hydraulic head difference between the specimen top cap and bottom cap, and an air/water interface panel for regulating the confining fluid pressure and backpressure (Fig. F4). Signals from the differential pressure transducer permit calculations of hydraulic head difference $(\Delta h)$ at a precision of $\pm 1 \mathrm{~cm} \mathrm{H}_{2} \mathrm{O}$ over a range of $\pm 1000 \mathrm{~cm}$ $\mathrm{H}_{2} \mathrm{O}$. A digital interface also records values of effective isotropic confining stress and elapsed time. A syringe pump (KDS Scientific, Model 260) simultaneously injects and extracts pore fluid from opposite ends of the specimen. The flow pump holds one syringe (Hamilton GasTight Series 1000) to infuse pore fluid into one end while another syringe withdraws an equal volume of fluid from the other end at the same rate. During the tests described here, volumetric 
flow rate $(Q)$ ranged from $2.0 \times 10^{-4} \mathrm{~cm}^{3} / \mathrm{min}$ to $8.0 \times$ $10^{-4} \mathrm{~cm}^{3} / \mathrm{min}$.

\section{Backpressure saturation}

Prior to each test, all permeant lines and porous stones were saturated with simulated seawater (25 g $\mathrm{NaCl}$ to $1 \mathrm{~L}$ tap water). After placing a specimen on the pedestal, the top cap was attached, and a latex membrane was added to encase the cylinder using a vacuum membrane expander. The confining chamber was then sealed, and the cell was filled with tap water. Saturation was achieved by ramping porefluid backpressure to $0.48 \mathrm{MPa}$ (70 psi) using the panel board (air/water interface) while also ramping the confining pressure to maintain an effective isotropic confining stress of $0.034 \mathrm{MPa}(5 \mathrm{psi})$. The elevated backpressure was maintained for at least $24 \mathrm{~h}$. We confirmed saturation by increasing the confining pressure to $0.55 \mathrm{MPa}(80 \mathrm{psi})$ and measuring the corresponding pore pressure $(u)$ response over the change in stress $(\sigma)$, which yields Skempton's $B$-value $(B=\Delta u / \Delta \sigma)$. Following the precedent of Yue et al. (2012), we judged the specimen to be saturated if either $B \geq 0.95$ (Table T1) or a $B$ value $<0.95$ remained constant for $>48 \mathrm{~h}$. After saturation, the cell pressure was increased to consolidate the specimen at an isotropic effective stress of $0.28 \mathrm{MPa}$ (40 psi). Pore water drained during consolidation from both the top and bottom of the specimen by opening valves on the confining cell. The volume of expelled pore water was measured using the backpressure pipette and monitored for equilibrium to calculate the corresponding volume change of the specimen. After finishing tests at $0.28 \mathrm{MPa}$, the specimen was consolidated further and tested again at an effective stress of $0.55 \mathrm{MPa}$ (80 psi).

\section{Constant-flow tests}

Two samples were tested under the two isotropic effective stresses of $0.28 \mathrm{MPa}$ (40 psi) and $0.55 \mathrm{MPa}(80$ psi). The third sample was tested only under 0.28 MPa because the cylinder fell apart during loading to $0.55 \mathrm{MPa}$ (Table T1). The normal protocol consists of two runs from top to bottom (denoted as a negative flow value) and two runs from bottom to top (denoted as a positive flow value) (Fig. F5). We monitored the transient response from the differential pressure transducer. Plots of applied discharge velocity $(v)$ and steady-state hydraulic gradient $\left(i_{s}\right)$ allow for visual assessments of consistency and linearity (see Appendix Figs. AF1, AF2, and AF3). Yue et al. (2012) regarded such data as "reliable" if the coefficient of determination $\left(R^{2}\right)$, calculated by leastsquared linear regression of those values, is $>0.9835$.

\section{Data reduction}

We calculated the value of hydraulic conductivity $(K$, in meters per second) for each specimen using Darcy's Law:

$$
\mathrm{Q}=K i_{\mathrm{s}} \mathrm{A}=K\left(\Delta h_{\mathrm{s}} / \Delta \mathrm{L}\right) \mathrm{A},
$$

where

$\mathrm{Q}=$ applied volumetric flow rate $\left(\mathrm{cm}^{3} / \mathrm{s}\right)$,

$i_{s}=$ steady-state hydraulic gradient,

$\Delta h_{\mathrm{s}}=$ steady-state head difference,

$\Delta \mathrm{L}=$ length over which head difference occurs (initial height of the specimen), and

$\mathrm{A}=$ cross-sectional flow area (initial specimen area).

The corresponding value of discharge velocity was computed using $v=\mathrm{Q} / \mathrm{A}$. Conversion of hydraulic conductivity to values of intrinsic permeability $(k$, in square meters) takes the permeant properties into account:

$$
k=(K \mu) /(\rho g),
$$

where

$\mu=$ viscosity of permeant at room temperature (0.001 Pa.s),

$\rho=$ density of permeant $\left(1027 \mathrm{~kg} / \mathrm{m}^{3}\right)$, and

$\mathrm{g}=$ gravitational acceleration $\left(9.81 \mathrm{~m} / \mathrm{s}^{2}\right)$.

Room temperature was typically set at $72^{\circ} \mathrm{F}\left(22^{\circ} \mathrm{C}\right)$.

\section{Imaging microfabric}

Yue et al. (2012) provided a thorough description of the procedures used at the University of Missouri (USA) to image and characterize the preferred orientation of microfabric. To summarize, oriented specimens were cut using a razor blade after the flowthrough tests were finished (Fig. F6). Wet, uncoated, and unfixed surfaces were imaged using an FEI Quanta 600 FEG scanning electron microscope (SEM), which operates in environmental mode (ESEM) at $20 \mathrm{kV}$ with the specimen chamber pressure set at $400 \mathrm{~Pa}$. Water vapor ( 98\% humidity) from a built-in reservoir keeps specimens from losing moisture with the cooling stage set to $2^{\circ} \mathrm{C}$. We used a gaseous backscattered electron detector, spot $=3.0$, and a working distance of $\sim 10 \mathrm{~mm}$. That combination generates an imaging resolution of $\sim 4 \mathrm{~nm}$, and the field of view is $\sim 150 \mathrm{~mm}$ across with $1000 \times$ magnification (Fig. F7).

Each gray-mode TIF image from the ESEM was processed for statistical analysis using ImageJ software (http://rsbweb.nih.gov/ij/index.html), which isolates the apparent dimensions of objects in a two-di- 
mensional image. We generally counted between 600 and 800 grains per image (depending on particle size) to calculate statistics for preferred grain orientation (Table T2). Each particle orientation (azimuth of the apparent long axis) is assigned to an angle between $0^{\circ}$ and $180^{\circ}$. For the vertical cut surface, the core axis is oriented at $90^{\circ}$. Rose diagrams were constructed using Rozeta software (http://www.softpedia.com/get/Science-CAD/Rozeta.shtml), which automatically assigns azimuths to bins at $10^{\circ}$ intervals. We plotted cumulative frequency curves to obtain graphical solutions of standard deviation $(d)$ according to Folk and Ward (1957) statistics:

$$
d=\left[\left(\varphi_{84}-\varphi_{16}\right) / 4\right]+\left[\left(\varphi_{95}-\varphi_{5}\right) / 6.6\right]
$$

where $\varphi_{84}, \varphi_{16}, \varphi_{95}$, and $\varphi_{5}$ represent the azimuth (in degrees) at the $84^{\text {th }}, 16^{\text {th }}, 95^{\text {th }}$, and $5^{\text {th }}$ percentiles. In this context, the largest possible value of $d$ is $72.3^{\circ}$ (i.e., a case in which $\varphi_{16}$ and $\varphi_{5}=0^{\circ}$ and $\varphi_{84}$ and $\varphi_{95}=$ $\left.180^{\circ}\right)$. To compare each standard deviation to this maximum $d$ value we calculated the "index of microfabric orientation" (i) as

$$
i=1-(d / 72.3) .
$$

With random arrangements of particles, the cumulative curve is relatively flat (slope $<0.75$ ) near the median, $d>35^{\circ}$, and $i<0.5$. As particles attain better parallel alignment, azimuths cluster more tightly, the slope of the cumulative curve steepens (slope $>$ 1.00) near the median, $d<25^{\circ}$, and $i>0.65$ (Yue et al., 2012).

\section{Energy dispersive X-ray spectroscopy}

Energy dispersive X-ray spectroscopy (EDS) was used to compare relative elemental proportions from measuring spots on selected SEM images. The SEM is equipped with a Bruker QUANTAX 200 high-speed silicon drift detector. A representative example of the spectrum for typical silicate minerals is shown in Figure F8 (Sample 348-C0002P-4R-2, $98 \mathrm{~cm}$ ).

\section{Results}

\section{Textural and compositional characterization}

Shipboard scientists used visual inspection to classify the dominant lithology of WR core samples as silty claystone to clayey siltstone. One sample (348C0002P-4R-2, $98 \mathrm{~cm}$ ) contains a clearly defined bed of siltstone (Fig. F3), and millimeter-scale heterogeneities also exist in the other specimens. We used SEM and EDS to quantify the differences in grain size and characterize minor compositional constituents (e.g., pyrite) in greater detail (Fig. F8). Additional images are included in the Appendix (Figs. AF4, AF5, AF6, AF7, AF8, and AF9). Figures AF5 and AF9, for example, provide EDS documentation for specimens containing carbonate microfossils and authigenic barite.

Figure $\mathrm{F} 9$ shows a range of grain sizes in a specimen that was cut with random orientation from Sample 348-C0002P-3R-1, $51 \mathrm{~cm}$. Part of the image consists of coarse silt-size and fine sand-size grains (apparent diameters $=\sim 50-100 \mu \mathrm{m})$. Medium silt-size grains $(\sim 20-40 \mu \mathrm{m})$ dominate the other part. The coarser material also displays a greenish color (Fig. F9A).

Pyrite (FeS) is a common authigenic mineral in deepsea sediments (e.g., Berner, 1984) and has been noted in other specimens from the Nankai Trough (e.g., Egawa et al., 2015). Figure F10 shows pyrite framboids in a specimen that was cut from Sample $3 \mathrm{R}-1,51 \mathrm{~cm}$. The high counts of $\mathrm{S}$ and Fe match the black band identified from the shipboard visual descriptions and an X-ray computed tomography scan of the WR sample. Small amounts of pyrite also occur in the specimen cut from Sample 4R-2, $98 \mathrm{~cm}$. The individual particles are $\sim 1 \mu \mathrm{m}$ and collectively form spheroidal aggregates.

Figure F11 shows SEM images from Sample 348C0002P-4R-2, $98 \mathrm{~cm}$. The trimmed sample contains a prominent bed of medium siltstone oriented oblique to the core axis (Fig. F3). That layer is dominated by grains measuring $\sim 25 \mu \mathrm{m}$ (Fig. F11B). Smaller grains in the surrounding clayey siltstone are $\sim 12 \mu \mathrm{m}$ in apparent diameter. Figure F12 shows SEM images from Sample 348-C0002P-6R-1, $64 \mathrm{~cm}$. That clayey siltstone sample is comparatively homogeneous, and no obvious differences in grain size exist among the imaged portions of the specimen. The dominant particle size for that material is $\sim 12-15 \mu \mathrm{m}$.

\section{Microfabric statistics}

Figure F13 catalogs the rose diagrams of particle orientation and corresponding values of standard deviation and index of orientation (see Table T2 for statistics). The cumulative frequency curves are plotted on Figure F14, which shows the orthogonal pairs of ESEM images for specimens tested for permeability. In general, we see no visual evidence for preferred orientation of grains, particularly for specimens with higher contents of silt. As statistical confirmation, the standard deviation for grain orientation ranges from $53.6^{\circ}$ to $58.7^{\circ}$, and the index of orientation ranges from 0.19 to 0.26 . All such values are consistent with random arrangements of particles. The index of orientation increases slightly with depth, especially for measurements on the vertical cut face (Fig. F15). 


\section{Permeability}

Table T1 summarizes values of water content and porosity for trimmings measured before and after each flow-through test. The trimmings are not necessarily representative of the entire cylinder, especially for specimens containing pyrite bands and coarser siltstone laminae. Two sections (348-C0002P-4R-2 and 6R-1) yielded pretest values of water content lower than the shipboard values. Those differences probably were caused by moisture loss during the shipment and storage of the WR specimens. In addition, we note that trimmings dried out quickly during the sample preparation. For Section 4R-2, the pretest porosity is also lower than post-test porosity. That specimen was particularly indurated, so moisture was probably lost during the longer time required for trimming. For Sample 348-C0002P-3R-1, $57 \mathrm{~cm}$, the shipboard value of porosity is lower than either pretest or post-test porosity. Moisture may have been gained during the trimming procedure; a spray bottle was used to keep the sample saturated during trimming. Alternatively, the higher post-test value may be related to progressive expansion of waterfilled microcracks after unloading.

An illustration of each individual constant-flow test result is included in the Appendix (Figs. AF1, AF2, AF3). With one exception, we regard the test results as "reliable" because the coefficient of determination $\left(R^{2}\right)$ is $>0.9835$. The exception (Section 348-C0002P$6 \mathrm{R}-1$, at $0.28 \mathrm{MPa}$ ) yielded $R^{2}=0.9791$, and that specimen was probably compromised by microcracks; subtle cracks were observed during trimming. In addition, the flow response was notably erratic under the higher effective stress $(0.55 \mathrm{MPa})$. While trying to trim a second specimen, the material fragmented along those crack lines. Our primary goal was to test specimens with different textures, especially coarser turbidite layers. That goal was achieved by successfully testing Section 348-C0002P-4R-2, with its intact interbeds of siltstone and clayey siltstone.

Table T3 lists the average values of hydraulic conductivity and intrinsic permeability for each specimen. Table T4 lists values of volumetric flow rate, discharge velocity, steady-state head loss, steady-state hydraulic gradient, hydraulic conductivity, and intrinsic permeability for each test. The highest average value of vertical hydraulic conductivity $(K)$ is $2.68 \times 10^{-8} \mathrm{~cm} / \mathrm{s}$, with $k=2.66 \times 10^{-17} \mathrm{~m}^{2}$. The lowest average value of $K$ is $3.83 \times 10^{-9} \mathrm{~cm} / \mathrm{s}$, with $k=3.80 \times$ $10^{-18} \mathrm{~m}^{2}$. Figure F16 shows a comparison between values of vertical permeability from this study and data from other NanTroSEIZE sites along the $\mathrm{Ku}$ - mano transect, plotted as a function of burial depth. This compilation includes data from both flowthrough tests and constant rate of strain (CRS) consolidation tests, with values of effective stress ranging from 0.02 to $12.4 \mathrm{MPa}$. In general, permeability values for mudstones decrease with depth, although the scatter at any given depth extends over 5 orders of magnitude. Permeability values for shallow Site C0002 mudstones plot near the center of this range. The three deeper samples from Hole C0002P, including the coarser specimen from Section 4R-2, show no significant differences in permeability with respect to shallow mudstones at Site C0002.

Figure F17 displays the relation between permeability and post-test porosity for a compilation of mud and mudstone data from different subduction zones. The values of porosity have not been corrected for contents of smectite (i.e., the effects of interlayer water). The global trend shows a systematic decrease in permeability with decreases in porosity. Shallow mudstone samples from Site C0002 yield permeability values near the middle of the compilation, over a comparable range of $40 \%$ to $50 \%$ porosity. Permeability values from the deeper and less porous Hole C0002P samples are similar in order of magnitude to the results from shallow Site C0002 mudstone.

\section{Acknowledgments}

Samples were provided by the Integrated Ocean Drilling Program (IODP). We thank the Mantle Quest Japan crew, Marine Works Japan technicians, and shipboard scientists aboard the D/V Chikyu for their assistance in acquisition of samples during Expedition 348. The Consortium for Ocean Leadership provided funding (Task Order T348A58 to M. Underwood). We thank W. Likos and J. Bowders for valuable guidance on use of the constant-flow apparatus. E. Screaton provided a review of the manuscript.

\section{References}

Aplin, A.C., Matenaar, I.F., McCarty, D.K., and van der Pluijm, B.A., 2006. Influence of mechanical compaction and clay mineral diagenesis on the microfabric and pore-scale properties of deep-water Gulf of Mexico mudstones. Clays and Clay Minerals, 54(4):500-514. https:// doi.org/10.1346/CCMN.2006.0540411

Bennett, R.H., Fischer, K.M., Lavoie, D.L., Bryant, W.R., and Rezak, R., 1989. Porometry and fabric of marine clay and carbonate sediments: determinants of permeability. Marine Geology, 89(1-2):127-152. https:// doi.org/10.1016/0025-3227(89)90030-3 
Berner, R.A., 1984. Sedimentary pyrite formation: an update. Geochimica et Cosmochimica Acta, 48(4):605615. https://doi.org/10.1016/0016-7037(84)90089-9

Daigle, H., and Dugan, B., 2014. Data report: permeability, consolidation, stress state, and pore system characteristics of sediments from Sites C0011, C0012, and C0018 of the Nankai Trough. In Henry, P., Kanamatsu, T., Moe, K., and the Expedition 333 Scientists, Proceedings of the Integrated Ocean Drilling Program, 333: Tokyo (Integrated Ocean Drilling Program Management International, Inc.). https://doi.org/10.2204/ iodp.proc.333.201.2014

Dugan, B., and Daigle, H., 2011. Data report: permeability, compressibility, stress state, and grain size of shallow sediments from Sites C0004, C0006, C0007, and C0008 of the Nankai accretionary complex. In Kinoshita, M., Tobin, H., Ashi, J., Kimura, G., Lallemant, S., Screaton, E.J., Curewitz, D., Masago, H., Moe, K.T., and the Expedition 314/315/316 Scientists, Proceedings of the Integrated Ocean Drilling Program, 314/315/316:

Washington, DC (Integrated Ocean Drilling Program Management International, Inc.). https://doi.org/ 10.2204/iodp.proc.314315316.208.2011

Dugan, B., and Zhao, X., 2013. Data report: permeability of sediments from Sites C0011 and C0012, NanTroSEIZE Stage 2: subduction inputs. In Saito, S., Underwood, M.B., Kubo, Y., and the Expedition 322 Scientists, Proceedings of the Integrated Ocean Drilling Program, 322: Tokyo (Integrated Ocean Drilling Program Management International, Inc.). https://doi.org/10.2204/ iodp.proc.322.208.2013

Egawa, K., Nishimura, O., Izumi, S., Fukami, E., Jin, Y., Kida, M., Konno, Y., Yoneda, J., Ito, T., Suzuki, K., Nakatsuka, Y., and Nagao, J., 2015. Bulk sediment mineralogy of gas hydrate reservoir at the East Nankai offshore production test site. Marine and Petroleum Geology, 66(2):379-387. https://doi.org/10.1016/j.marpetgeo.2015.02.039

Ekinci, M.K., Likos, W.J., Underwood, M.B., and Guo, J., 2011. Data report: permeability of mud(stone) samples from IODP Sites C0006 and C0007, Nankai Trough Seismogenic Zone Experiment. In Kinoshita, M., Tobin, H., Ashi, J., Kimura, G., Lallemant, S., Screaton, E.J., Curewitz, D., Masago, H., Moe, K.T., and the Expedition 314/ 315/316 Scientists, Proceedings of the Integrated Ocean Drilling Program, 314/315/316: Washington, DC (Integrated Ocean Drilling Program Management International, Inc.). https://doi.org/10.2204/ iodp.proc.314315316.214.2011

Folk, R.L., and Ward, W.C., 1957. Brazos River bar [Texas]: a study in the significance of grain size parameters. Journal of Sedimentary Research, 27(1):3-26. https://doi.org/ 10.1306/74D70646-2B21-11D7-8648000102C1865D

Gamage, K., Screaton, E., Bekins, B., and Aiello, I., 2011. Permeability-porosity relationships of subduction zone sediments. Marine Geology, 279(1-4):19-36. https:// doi.org/10.1016/j.margeo.2010.10.010

Guo, J., Likos, W.J., Underwood, M.B., Skarbek, R.M., Adamson, N., and Saffer, D., 2011. Data report: consolidation characteristics of sediments from Sites C0002,
C0006, and C0007, IODP Expeditions 315 and 316, NanTroSEIZE Stage 1. In Kinoshita, M., Tobin, H., Ashi, J., Kimura, G., Lallemant, S., Screaton, E.J., Curewitz, D., Masago, H., Moe, K.T., and the Expedition 314/315/316 Scientists, Proceedings of the Integrated Ocean Drilling Program, 314/315/316: Washington, DC (Integrated Ocean Drilling Program Management International, Inc.). https://doi.org/10.2204/

iodp.proc.314315316.213.2011

Guo, J., and Underwood, M.B., 2014. Data report: consolidation and permeability of sediments from Sites C0011, C0012, and C0018, IODP Expeditions 322 and 333, NanTroSEIZE Stage 2. In Saito, S., Underwood, M.B., Kubo, Y., and the Expedition 322 Scientists, Proceedings of the Integrated Ocean Drilling Program, 322: Tokyo (Integrated Ocean Drilling Program Management International, Inc.). https://doi.org/10.2204/ iodp.proc.322.209.2014

Hüpers, A., and Kopf, A.J., 2012. Data report: consolidation properties of silty claystones and sandstones sampled seaward of the Nankai Trough subduction zone, IODP Sites C0011 and C0012. In Saito, S., Underwood, M.B., Kubo, Y., and the Expedition 322 Scientists, Proceedings of the Integrated Ocean Drilling Program, 322: Tokyo (Integrated Ocean Drilling Program Management International, Inc.). https://doi.org/10.2204/ iodp.proc.322.203.2012

Ichinose, G.A., Thio, H.K., Somerville, P.G., Sato, T., and Ishii, T., 2003. Rupture process of the 1944 Tonankai earthquake $\left(M_{S} 8.1\right)$ from the inversion of teleseismic and regional seismograms. Journal of Geophysical Research: Solid Earth, 108(B10):2497. https://doi.org/ 10.1029/2003JB002393

Moon, C.F., and Hurst, C.W., 1984. Fabrics of muds and shales: an overview. In Stow, D.A.V., and Piper, D.J.W. (Eds.), Fine-Grained Sediments: Deep-Water Processes and Facies. Geological Society Special Publication, 15(1):579-593. https://doi.org/10.1144/ GSL.SP.1984.015.01.36

Neuzil, C.E., 1994. How permeable are clays and shales? Water Resources Research, 30(2):145-150. https:// doi.org/10.1029/93WR02930

Rowe, K., Screaton, E., Guo, J., and Underwood, M.B., 2011. Data report: permeabilities of sediments from the Kumano Basin transect off Kii Peninsula, Japan. In Kinoshita, M., Tobin, H., Ashi, J., Kimura, G., Lallemant, S., Screaton, E.J., Curewitz, D., Masago, H., Moe, K.T., and the Expedition 314/315/316 Scientists, Proceedings of the Integrated Ocean Drilling Program, 314/315/ 316: Washington, DC (Integrated Ocean Drilling Program Management International, Inc.). https:// doi.org/10.2204/iodp.proc.314315316.211.2011

Rowe, K.T., Screaton, E.J., and Ge, S., 2012. Coupled fluid flow and deformation modeling of the frontal thrust region of the Kumano Basin transect, Japan: implications for fluid pressures and décollement downstepping. Geochemistry, Geophysics, Geosystems, 13:Q0AD23. https://doi.org/10.1029/2011GC003861

Saffer, D., Guo, J., Underwood, M.B., Likos, W., Skarbek, R.M., Song, I., and Gildow, M., 2011. Data report: con- 
solidation, permeability, and fabric of sediments from the Nankai continental slope, IODP Sites C0001, C0008, and C0004. In Kinoshita, M., Tobin, H., Ashi, J., Kimura, G., Lallemant, S., Screaton, E.J., Curewitz, D., Masago, H., Moe, K.T., and the Expedition 314/315/316 Scientists, Proceedings of the Integrated Ocean Drilling Program, 314/315/316: Washington, DC (Integrated Ocean Drilling Program Management International, Inc.). https:// doi.org/10.2204/iodp.proc.314315316.218.2011

Screaton, E., Rowe, K., Sutton, J., and Atalan, G., 2013. Data report: permeabilities of Expedition 322 and 333 sediments from offshore the Kii Peninsula, Japan. In Saito, S., Underwood, M.B., Kubo, Y., and the Expedition 322 Scientists, Proceedings of the Integrated Ocean Drilling Program, 322: Tokyo (Integrated Ocean Drilling Program Management International, Inc.). https:// doi.org/10.2204/iodp.proc.322.210.2013

Tobin, H., Hirose, T., Saffer, D., Toczko, S., Maeda, L., Kubo, Y., Boston, B., Broderick, A., Brown, K., Crespo-Blanc, A., Even, E., Fuchida, S., Fukuchi, R., Hammerschmidt, S., Henry, P., Josh, M., Jurado, M.J., Kitajima, H., Kitamura, M., Maia, A., Otsubo, M., Sample, J., Schleicher, A., Sone, H., Song, C., Valdez, R., Yamamoto, Y., Yang, K., Sanada, Y., Kido, Y., and Hamada, Y., 2015a. Expedition 348 summary. In Tobin, H., Hirose, T., Saffer, D., Toczko, S., Maeda, L., Kubo, Y., and the Expedition 348 Scientists, Proceedings of the Integrated Ocean Drilling Program, 348: College Station, TX (Integrated Ocean Drilling Program). https://doi.org/10.2204/ iodp.proc.348.101.2015

Tobin, H., Hirose, T., Saffer, D., Toczko, S., Maeda, L., Kubo, Y., Boston, B., Broderick, A., Brown, K., Crespo-Blanc, A., Even, E., Fuchida, S., Fukuchi, R., Hammerschmidt, S., Henry, P., Josh, M., Jurado, M.J., Kitajima, H., Kitamura, M., Maia, A., Otsubo, M., Sample, J., Schleicher, A., Sone, H., Song, C., Valdez, R., Yamamoto, Y., Yang,
K., Sanada, Y., Kido, Y., and Hamada, Y., 2015b. Methods. In Tobin, H., Hirose, T., Saffer, D., Toczko, S., Maeda, L., Kubo, Y., and the Expedition 348 Scientists, Proceedings of the Integrated Ocean Drilling Program, 348: College Station, TX (Integrated Ocean Drilling Program). https://doi.org/10.2204/ iodp.proc.348.102.2015

Tobin, H., Hirose, T., Saffer, D., Toczko, S., Maeda, L., Kubo, Y., Boston, B., Broderick, A., Brown, K., Crespo-Blanc, A., Even, E., Fuchida, S., Fukuchi, R., Hammerschmidt, S., Henry, P., Josh, M., Jurado, M.J., Kitajima, H., Kitamura, M., Maia, A., Otsubo, M., Sample, J., Schleicher, A., Sone, H., Song, C., Valdez, R., Yamamoto, Y., Yang, K., Sanada, Y., Kido, Y., and Hamada, Y., 2015c. Site C0002. In Tobin, H., Hirose, T., Saffer, D., Toczko, S., Maeda, L., Kubo, Y., and the Expedition 348 Scientists, Proceedings of the Integrated Ocean Drilling Program, 348: College Station, TX (Integrated Ocean Drilling Program). https://doi.org/10.2204/ iodp.proc.348.103.2015

Yue, L., Likos, W.J., Guo, J., and Underwood, M.B., 2012. Data report: permeability of mud(stone) samples from Site C0001, IODP Expedition 315, Nankai Trough: NanTroSEIZE Stage 1. In Kinoshita, M., Tobin, H., Ashi, J., Kimura, G., Lallemant, S., Screaton, E.J., Curewitz, D., Masago, H., Moe, K.T., and the Expedition 314/315/316 Scientists, Proceedings of the Integrated Ocean Drilling Program, 314/315/316: Washington, DC (Integrated Ocean Drilling Program Management International, Inc.). https://doi.org/10.2204/ iodp.proc.3314315316.204.2012

Initial receipt: 23 February 2016

Acceptance: 1 May 2017

Publication: 7 July 2017

MS 348-201 
Figure F1. NanTroSEIZE transect area offshore southwest Japan with locations of IODP sites.

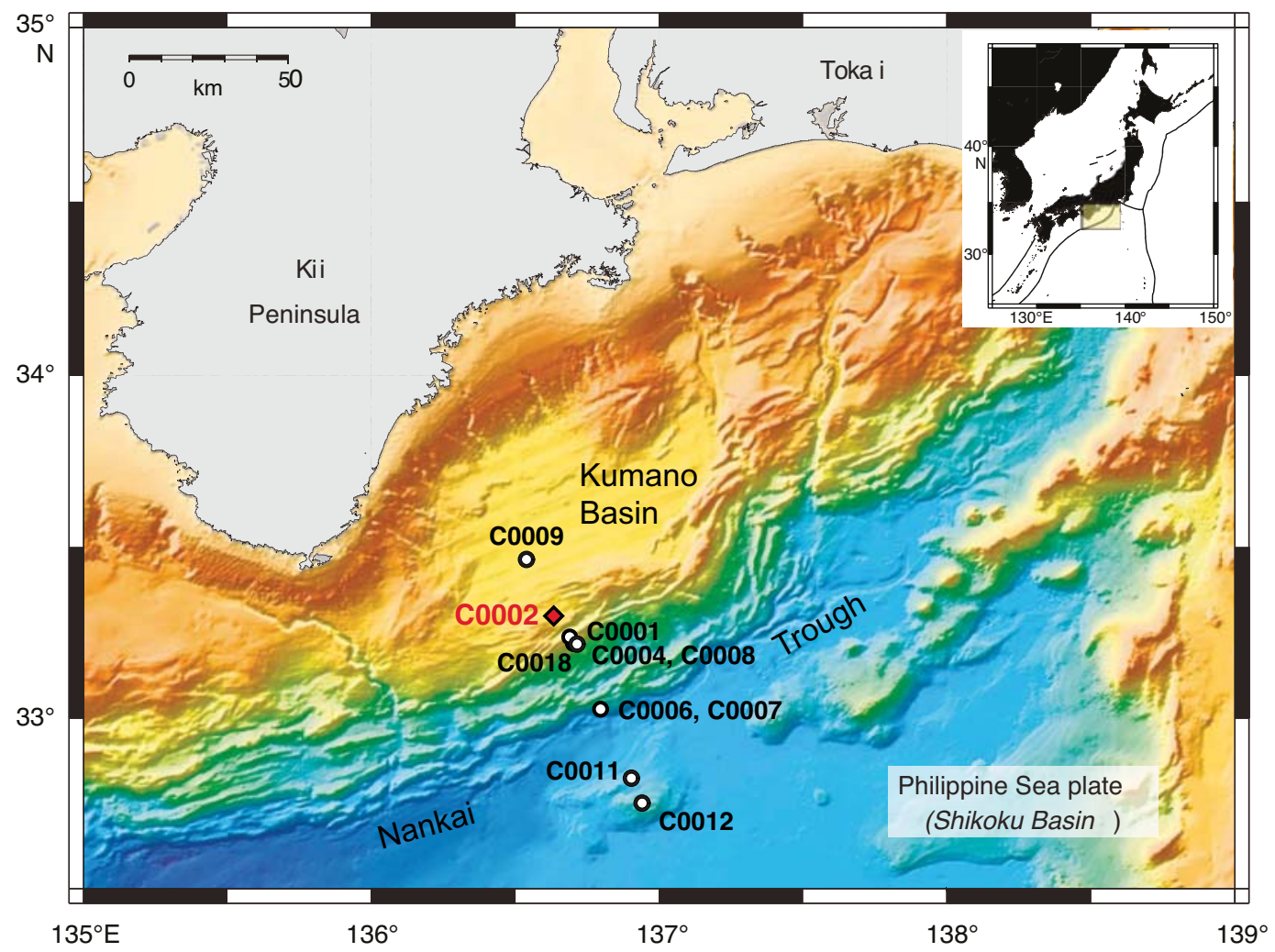


Figure F2. Stratigraphic columns and lithologic units for Site C0002 with positions of core samples used for permeability tests. Bedding dips are for closest nearby intervals in core as reported in the "Site C0002" chapter (Tobin et al., 2015c). Red circles $=$ successful tests, yellow circle $=$ specimen that failed during trimming.

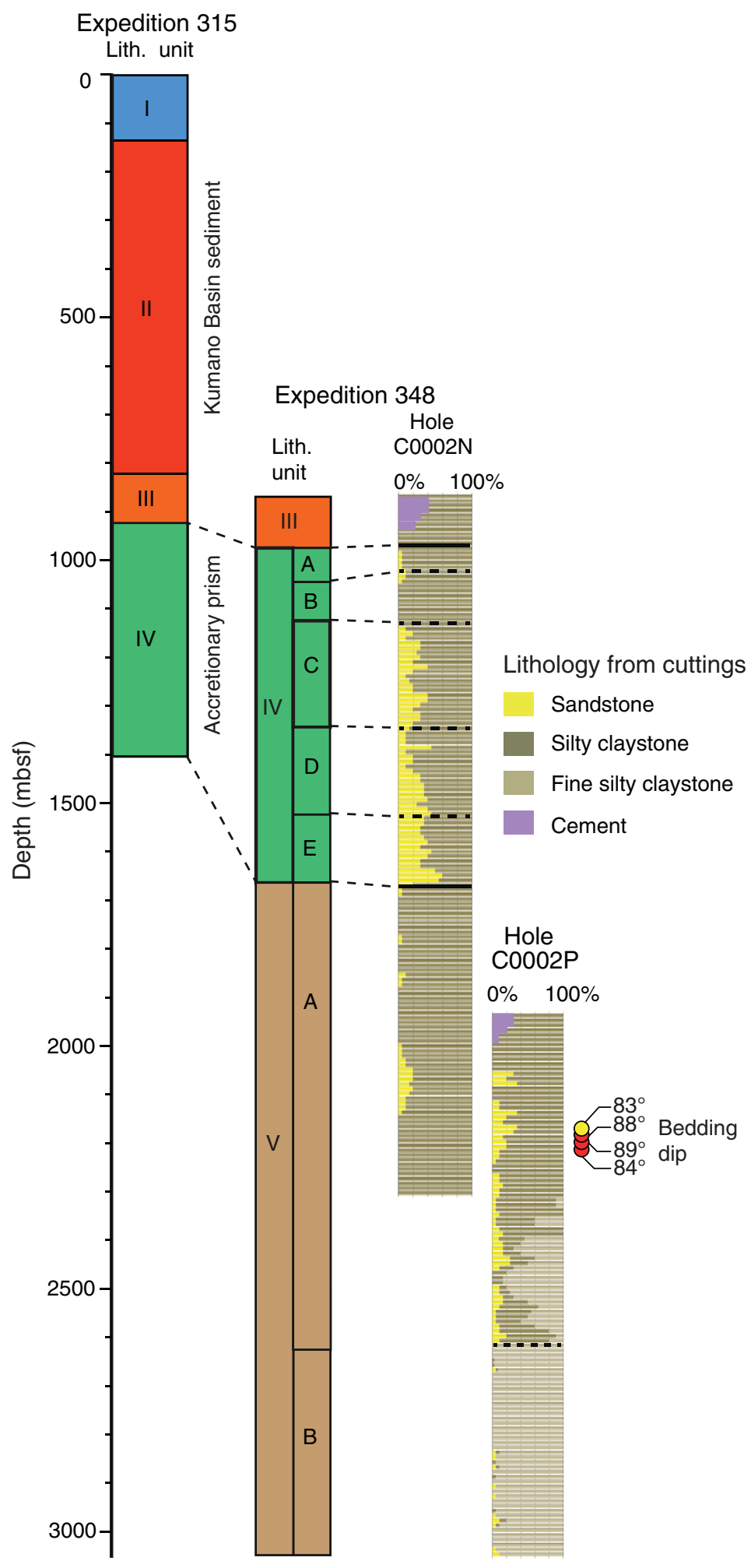


Figure F3. X-ray computed tomography (CT) scans, shipboard core images, and close-up images of wholeround sample intervals showing the three specimens from Hole C0002P tested successfully for permeability.

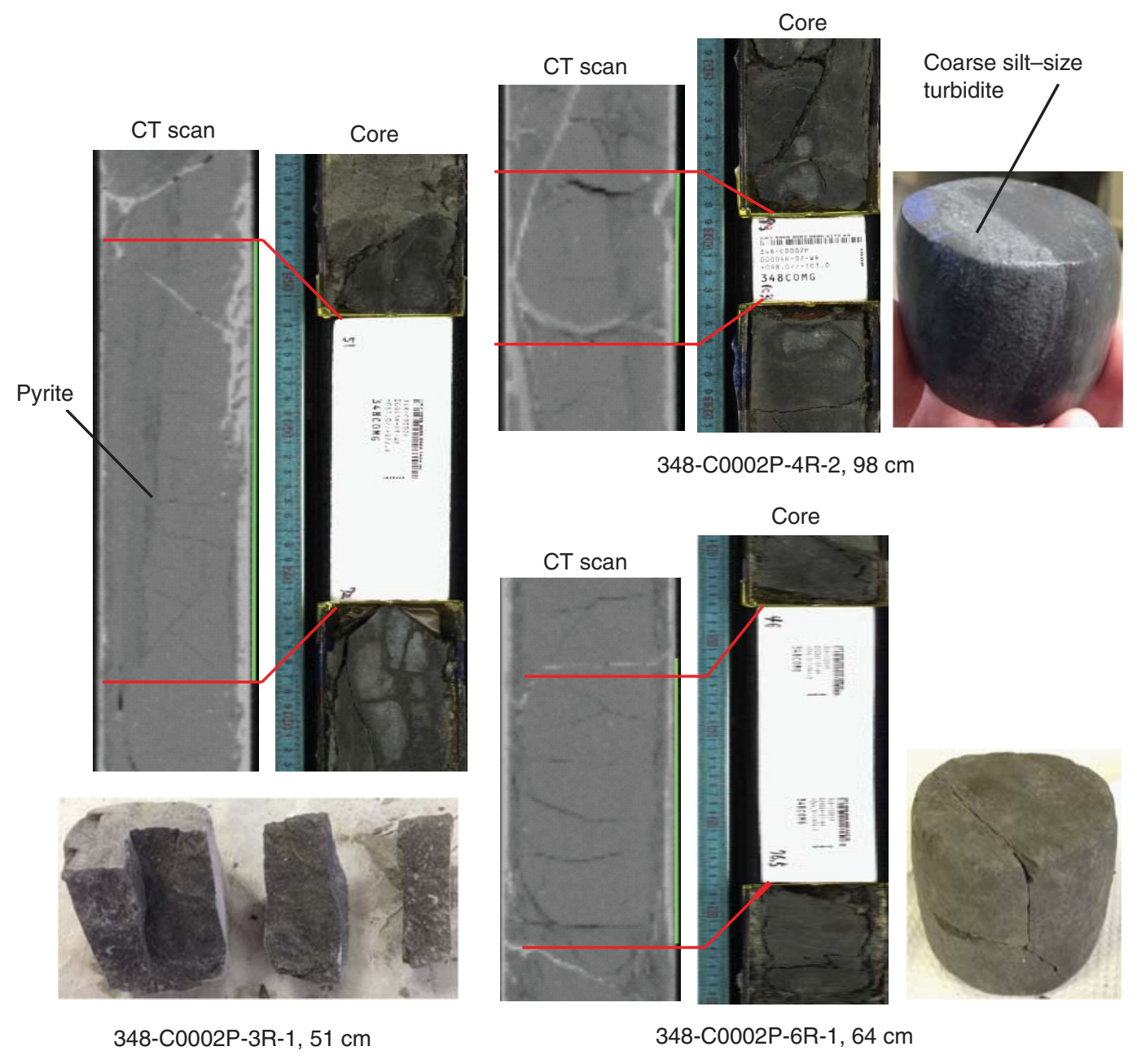


Figure F4. Schematic diagram of the testing system for constant-flow permeability at the University of Missouri (USA).

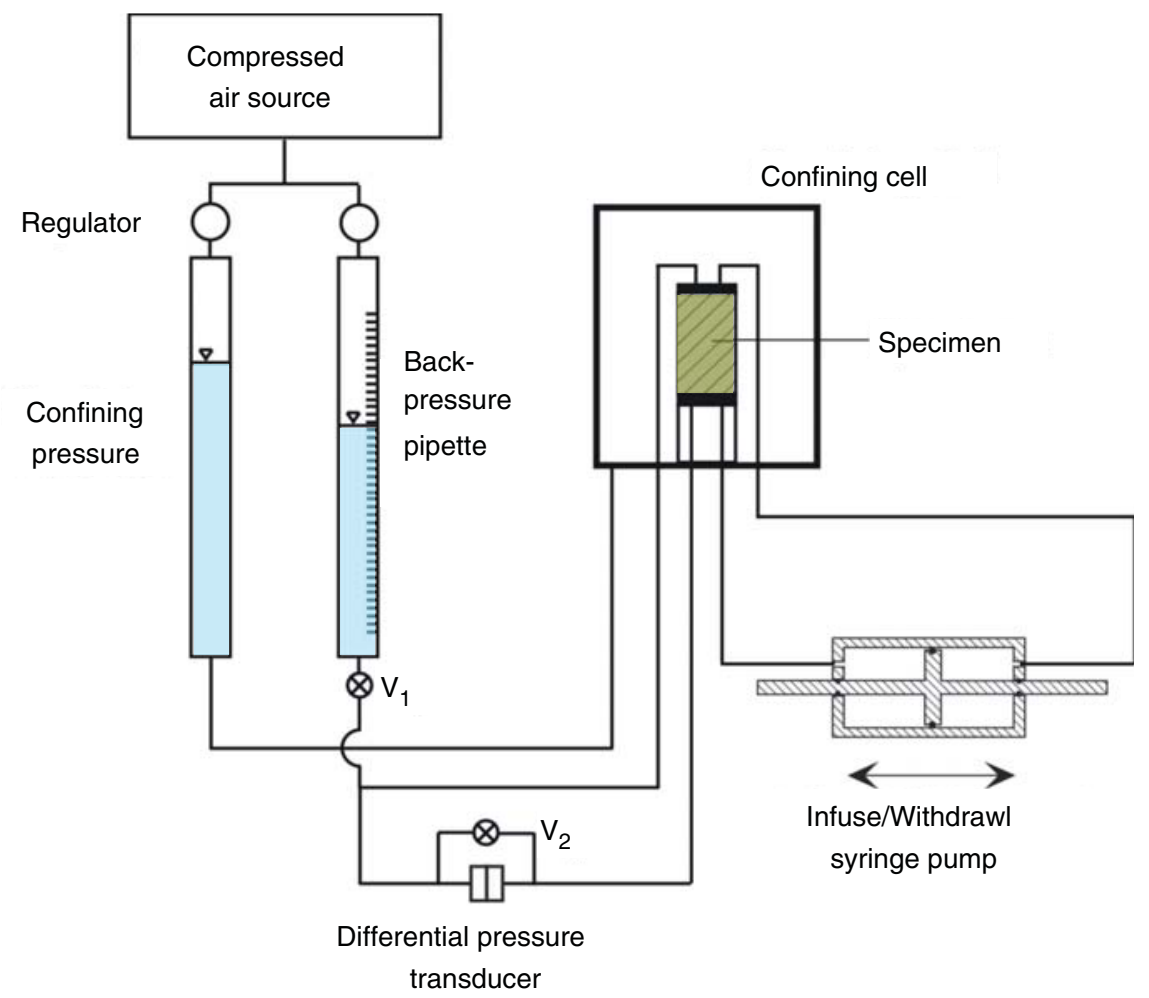

Figure F5. Example of typical responses of transient head difference $\left(\Delta h_{\mathrm{s}}\right)$ during flow-through testing. $Q=$ volumetric flow rate, $K=$ hydraulic conductivity. Confining pressure $=0.55 \mathrm{MPa}$.

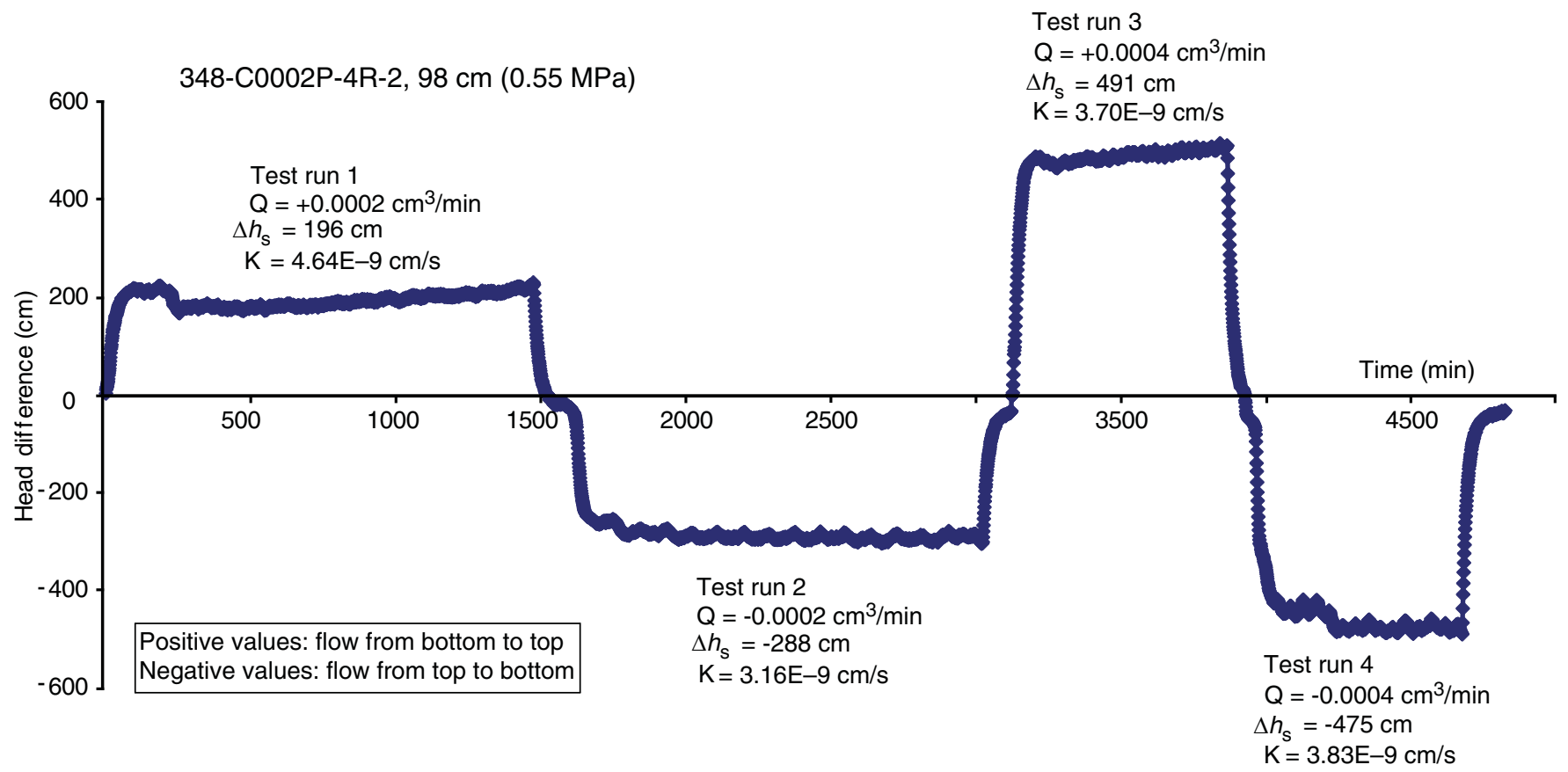


Figure F6. Schematic showing geometric relations among bedding, orientation of the core axis, and the horizontal and vertical sections used for imaging by ESEM. All specimens tested in this study display bedding dips $>80^{\circ}$.

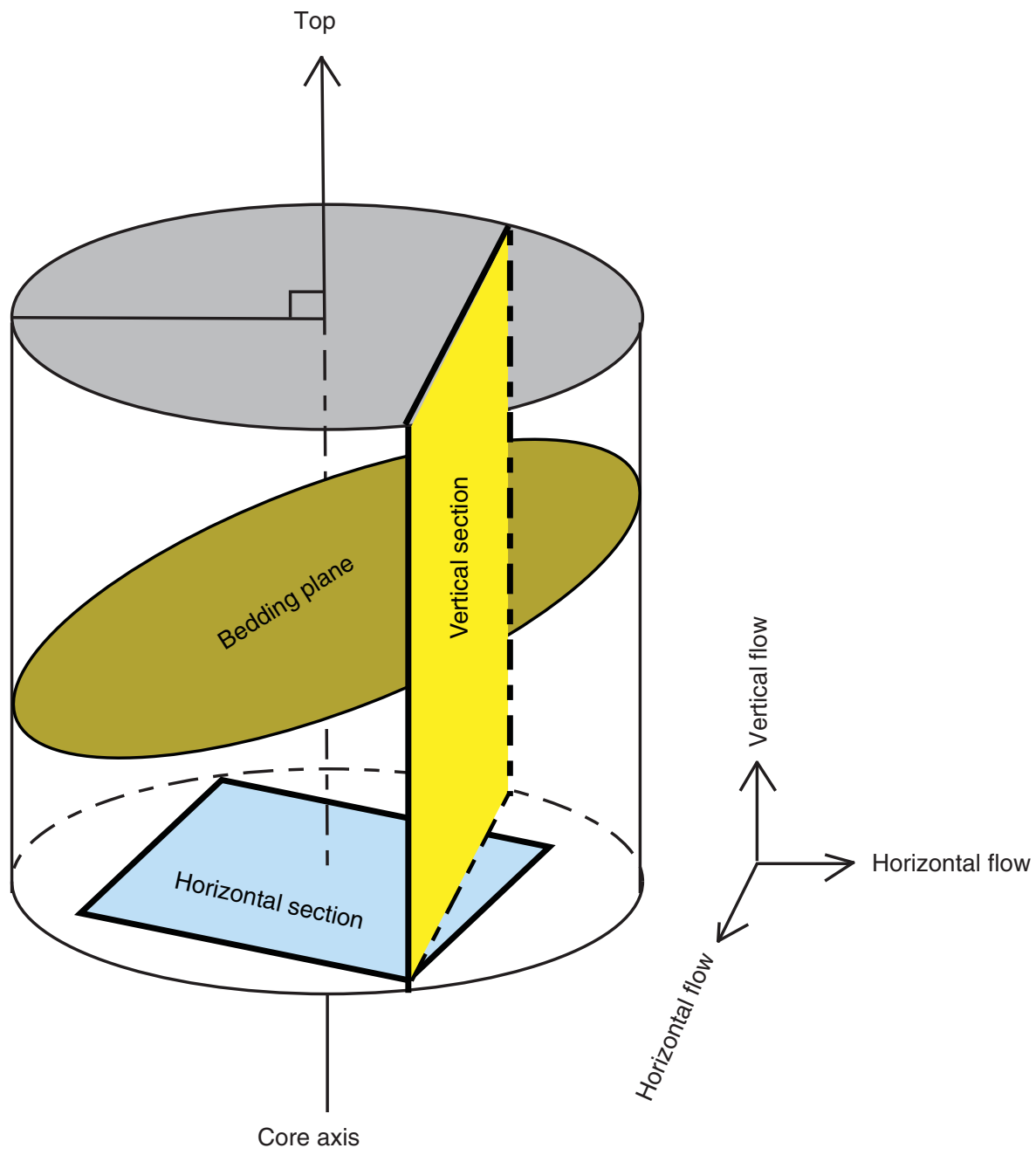


Figure F7. ESEM images of specimens tested for permeability, Hole C0002P. Sections were cut parallel (vertical) and perpendicular (horizontal) relative to the core axis. Cylindrical specimens for flow-through tests were trimmed parallel to core axis, subparallel to bedding. See Figure F2 and Table T1 for bedding dip angles near each sample interval.
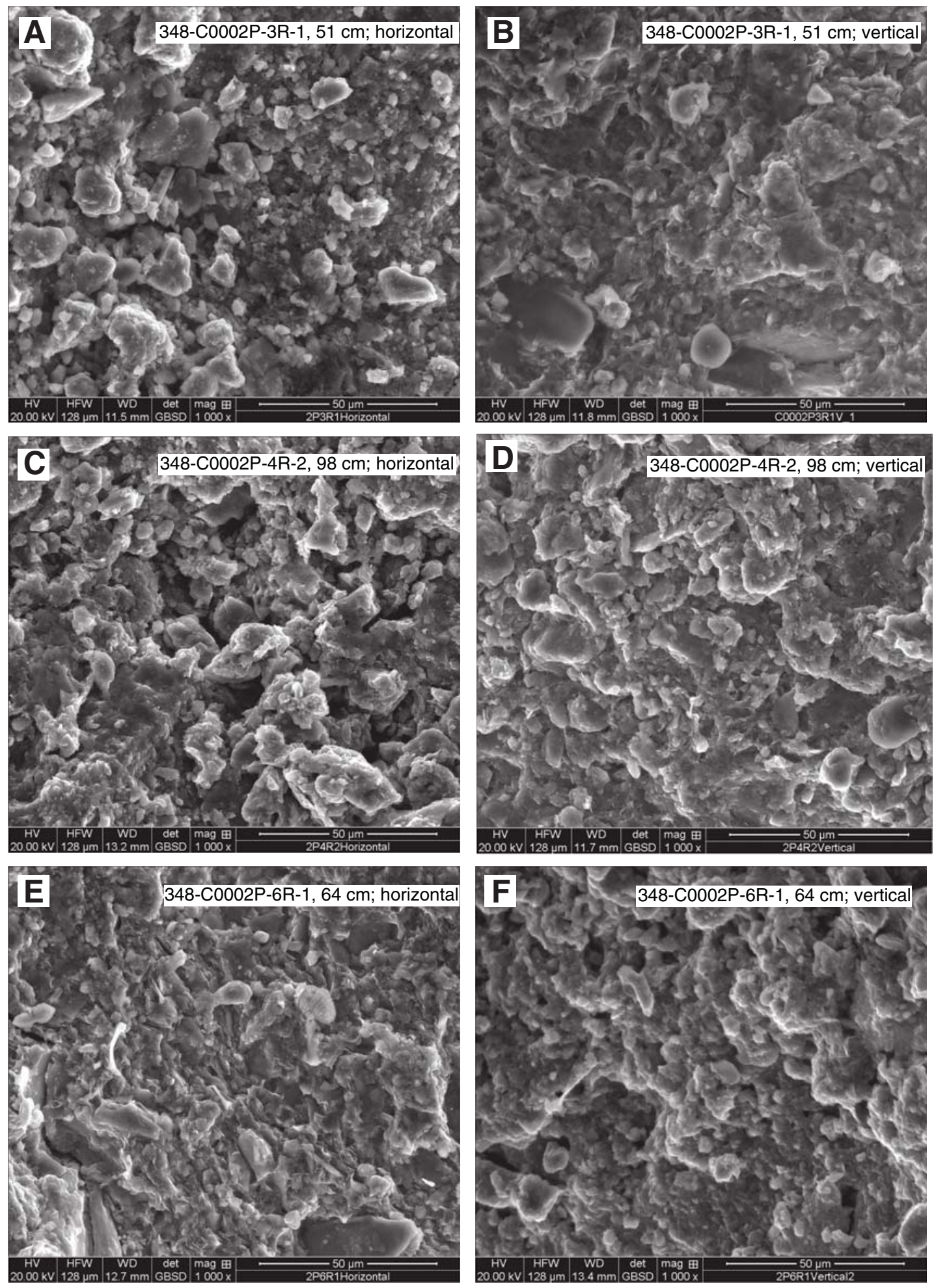
Figure F8. A. ESEM image of Sample 368-C0002P-4R-2, $98 \mathrm{~cm}$. B. Spectrum of major elements from energy dispersive X-ray spectroscopy from Point 1 in A. Elemental spectrum is consistent with the composition of quartz $\left(\mathrm{SiO}_{2}\right)$ with traces of clay minerals.

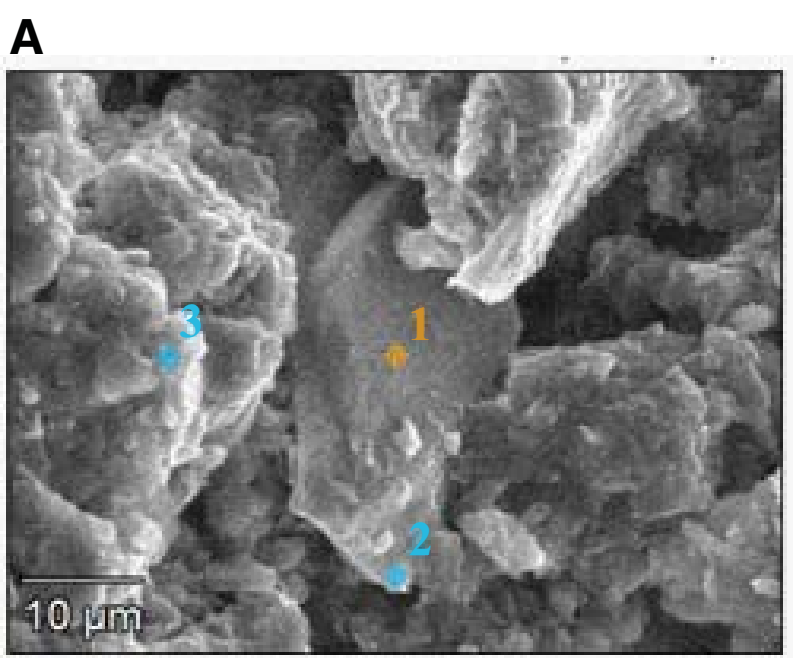

B

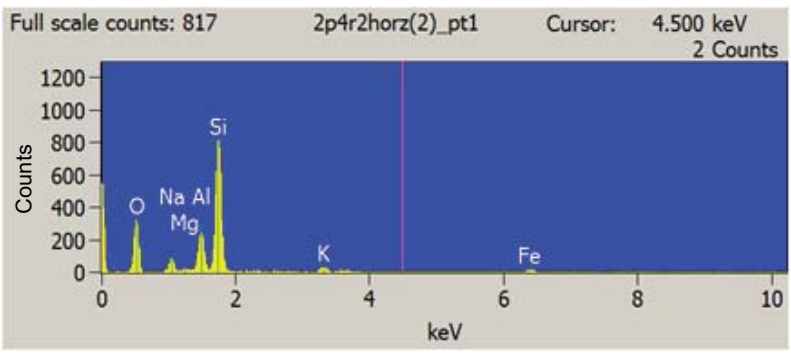


Figure F9. Images showing different grain sizes in Sample 348-C0002P-3R-1, $51 \mathrm{~cm}$. A. Trimmed specimen imaged by ESEM. Red line separates layers with different textures (coarse siltstone and silty claystone). B. ESEM image of coarse silt-size and fine sand-size grains, with impressions left from grain plucking. C. ESEM image showing boundary between coarse silt-size grains (upper left) and finer silt- and clay-size grains (bottom right). D. ESEM image of fine silt- and clay-size grains.

A

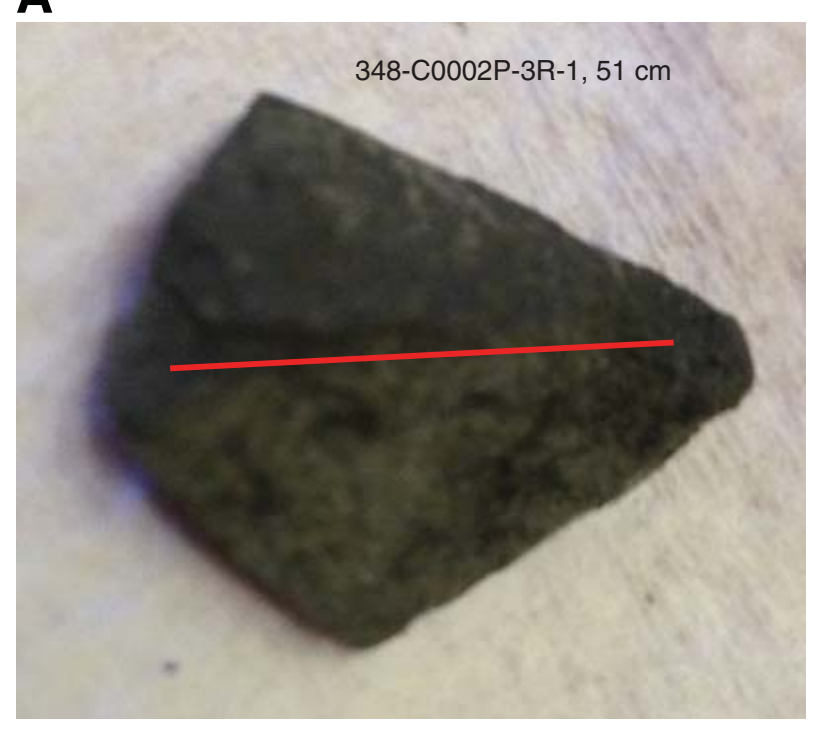

C

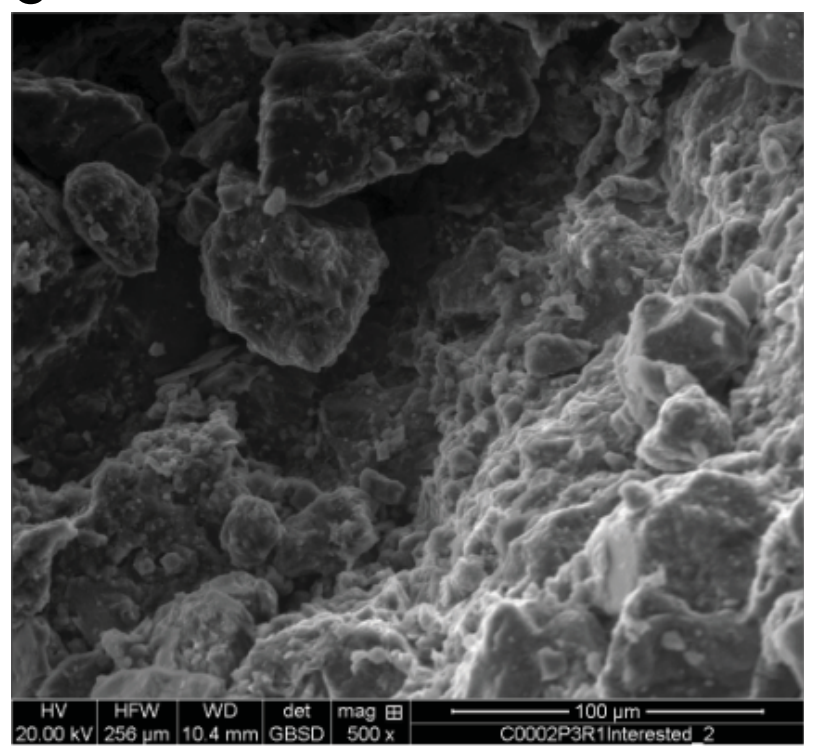

B

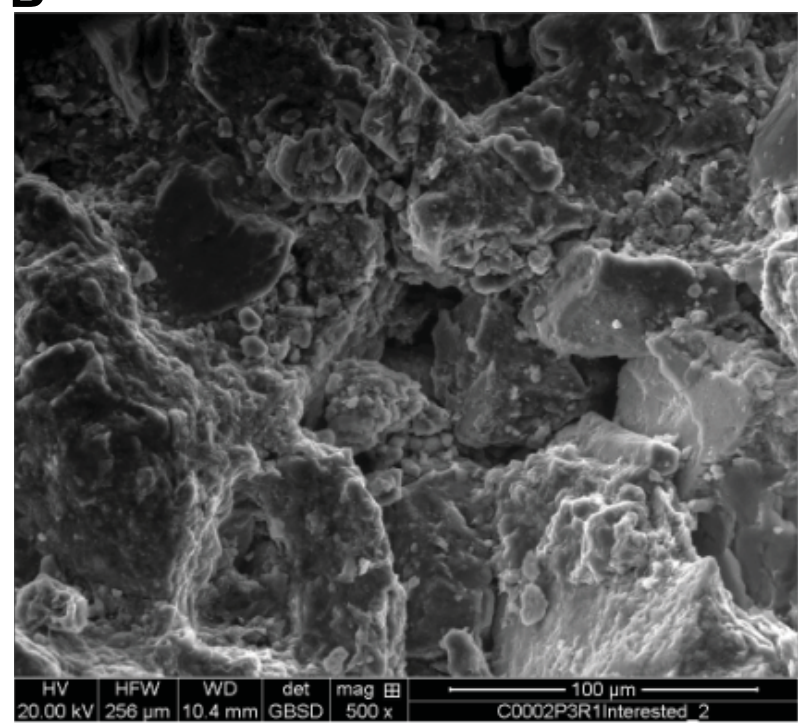

D

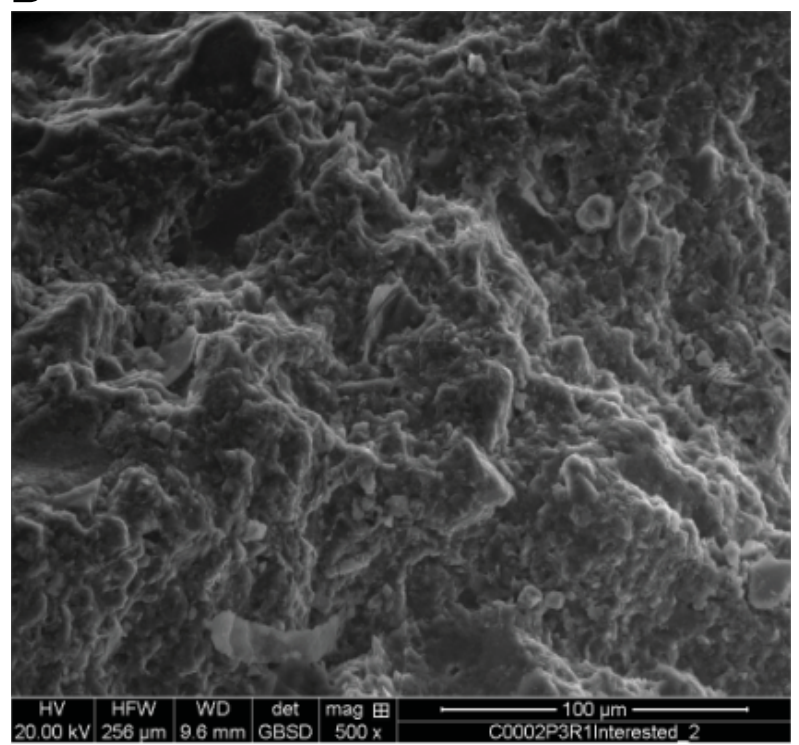


Figure F10. Pyrite framboid in Sample 348-C0002P-3R-1, $51 \mathrm{~cm}$. A. ESEM image. B. Image used for EDS analysis. C. EDS spectrum of major elements from Point 1 in B. Points 2 and 3 yielded similar results. Elemental spectrum is consistent with the composition of pyrite $\left(\mathrm{FeS}_{2}\right)$ with traces of clay minerals.

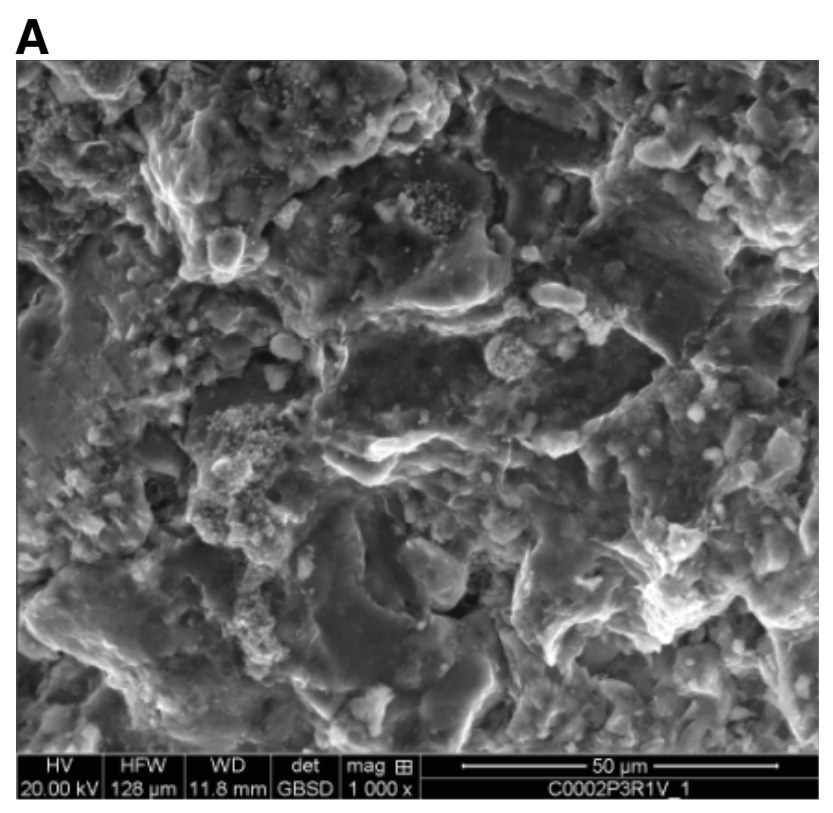

\section{B}

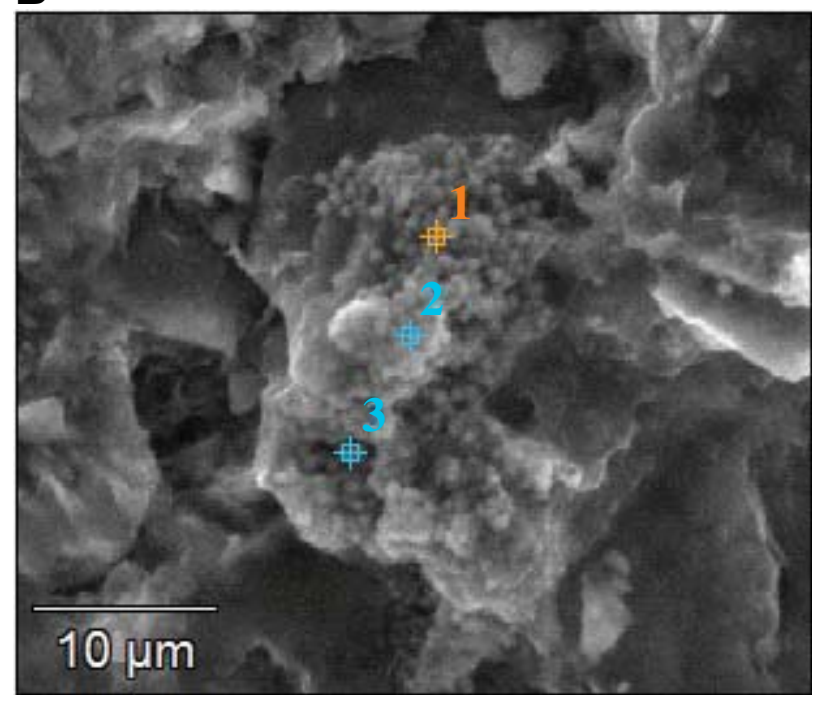

\section{C}

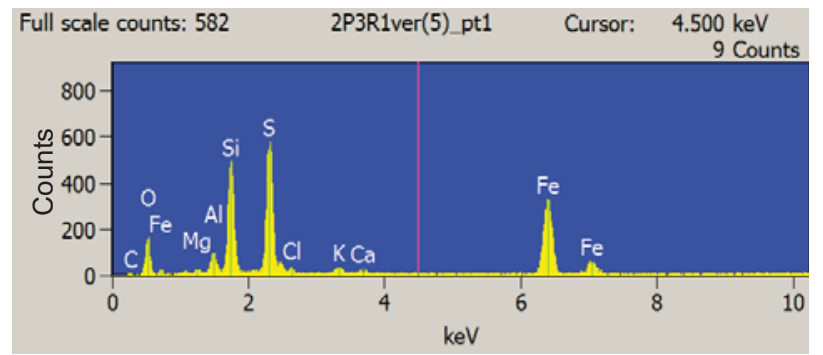


Figure F11. ESEM images of different grain sizes, Hole C0002P. A. Fine silt- and clay-size grains. B. Medium to coarse silt-size grains.

A

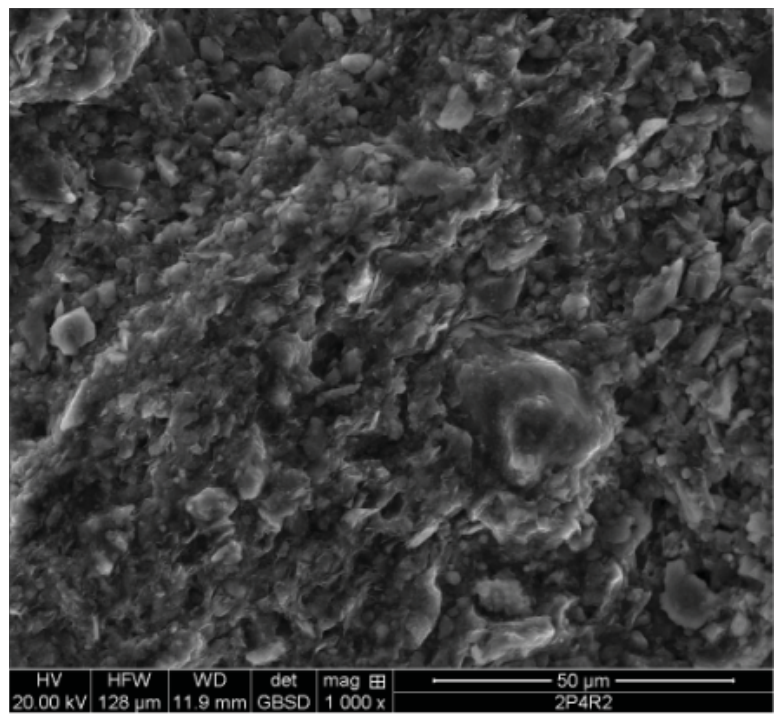

348-C0002P-6R-1, 64cm
B

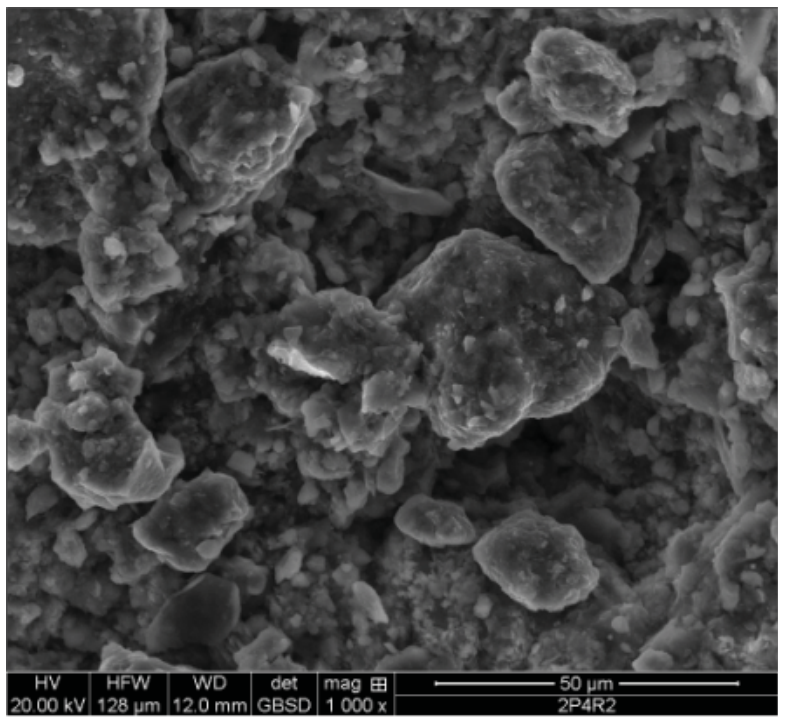

Figure F12. ESEM images showing relatively uniform grain size distribution, Hole C0002P.

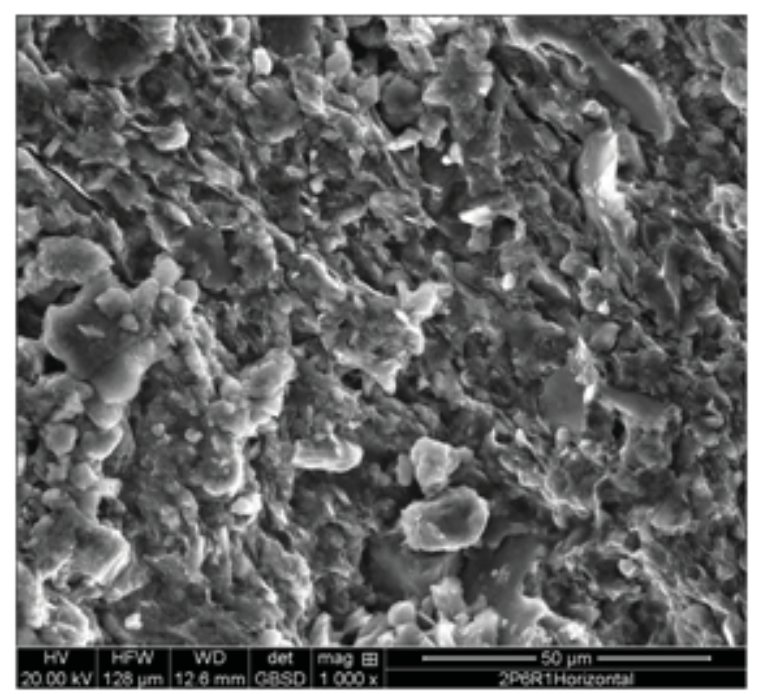

348-C0002P-6R-1, $64 \mathrm{~cm}$

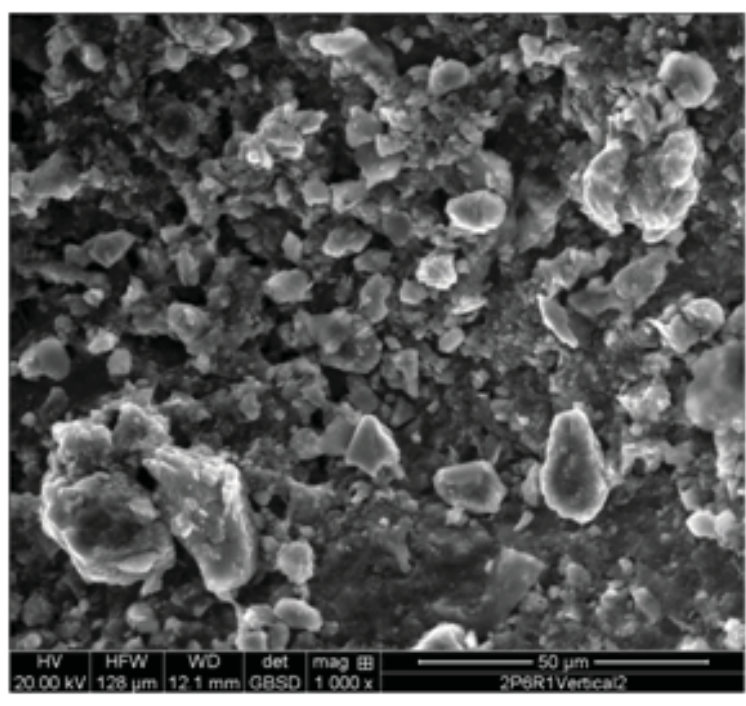


Figure F13. Orientation of grains (apparent long axis) measured on ESEM images. Relative to the core axis, sections were cut parallel (vertical) and perpendicular (horizontal). See Figure F7 for the corresponding ESEM images. Also shown are values of standard deviation $(d)$ for grain orientation and values of microfabric orientation index (i).

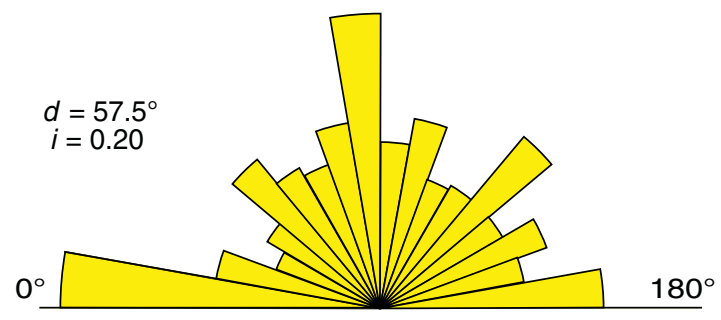

348-C0002P-3R-1, $51 \mathrm{~cm}$; horizontal

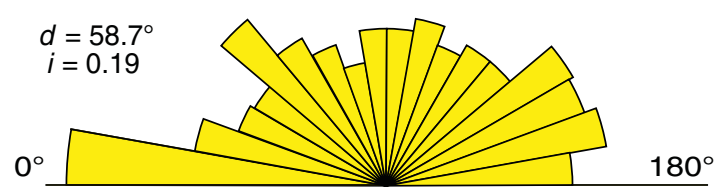

348-C0002P-4R-2, $98 \mathrm{~cm}$; horizontal

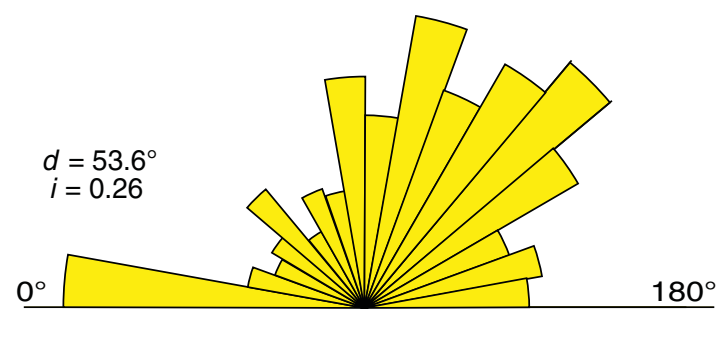

348-C0002P-6R-1, $64 \mathrm{~cm}$; horizontal

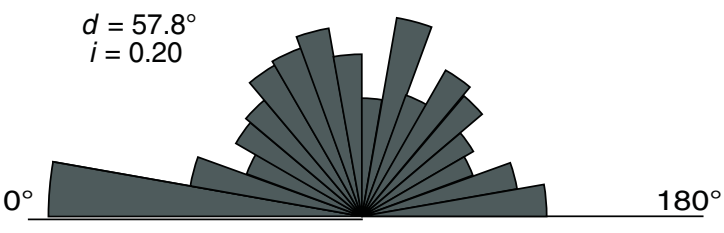

348-C0002P-3R-1, $51 \mathrm{~cm}$; vertical

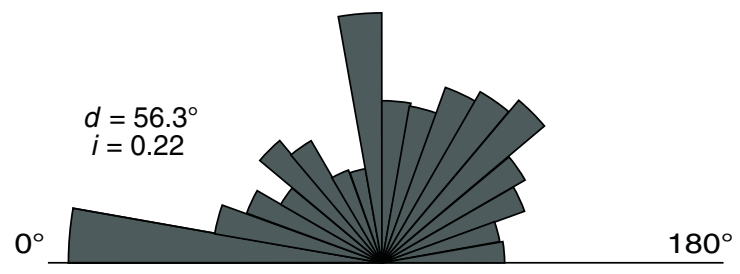

348-C0002P-4R-2, $98 \mathrm{~cm}$; vertical

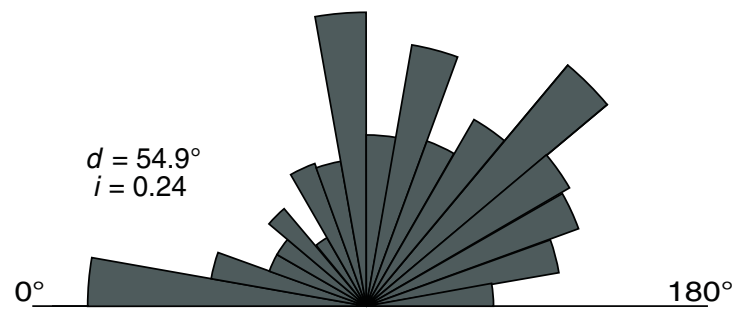

348-C0002P-6R-1, $64 \mathrm{~cm}$; vertical 
Figure F14. Cumulative frequency curves of grain orientations (apparent long axes) in Hole C0002P derived from analysis of ESEM images on horizontal (perpendicular to core axis) and vertical (parallel to core axis) sections. Linear trends are indicative of random grain orientations.
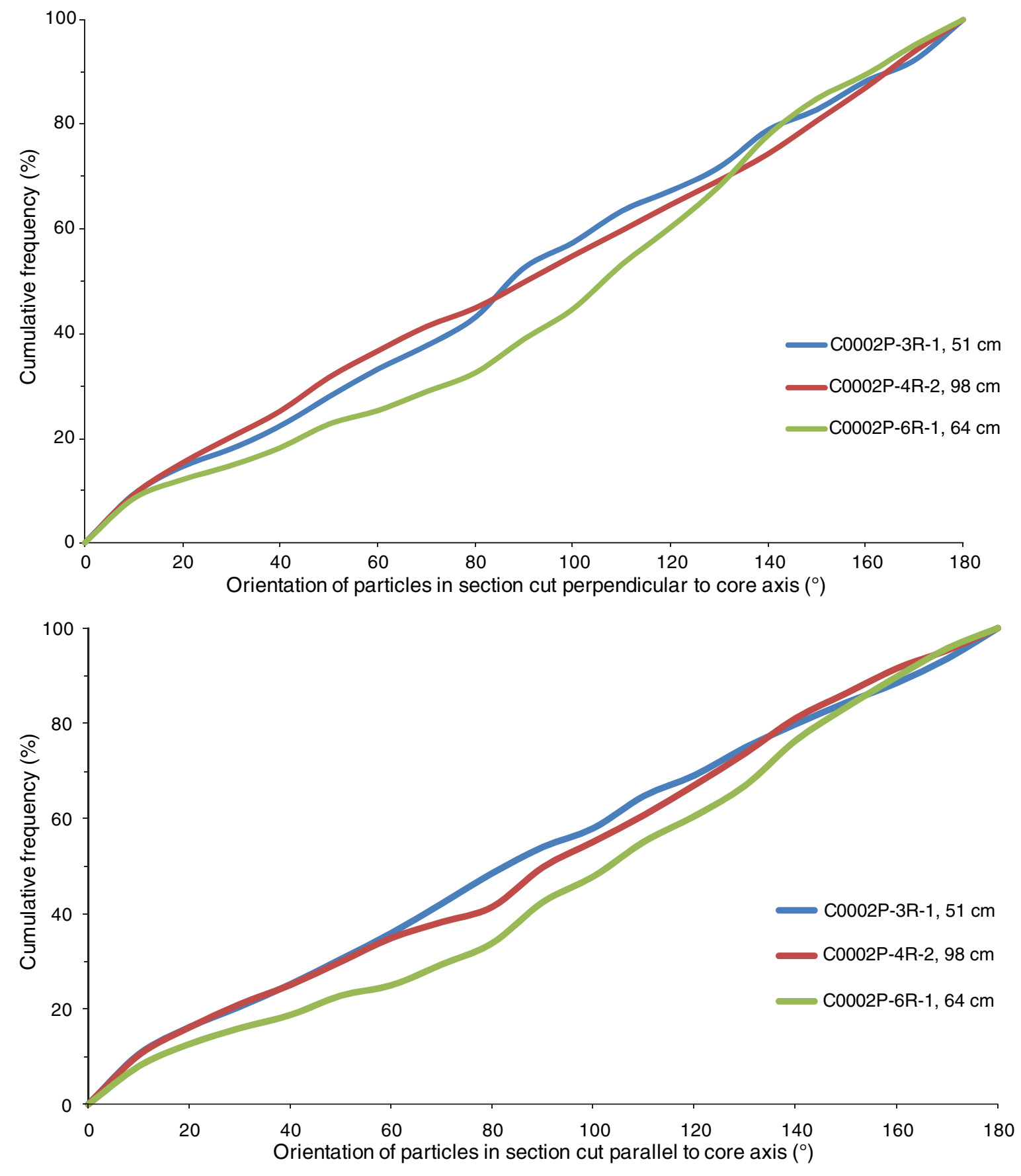
Figure F15. Index of orientation (horizontal and vertical sections), Hole C0002P.

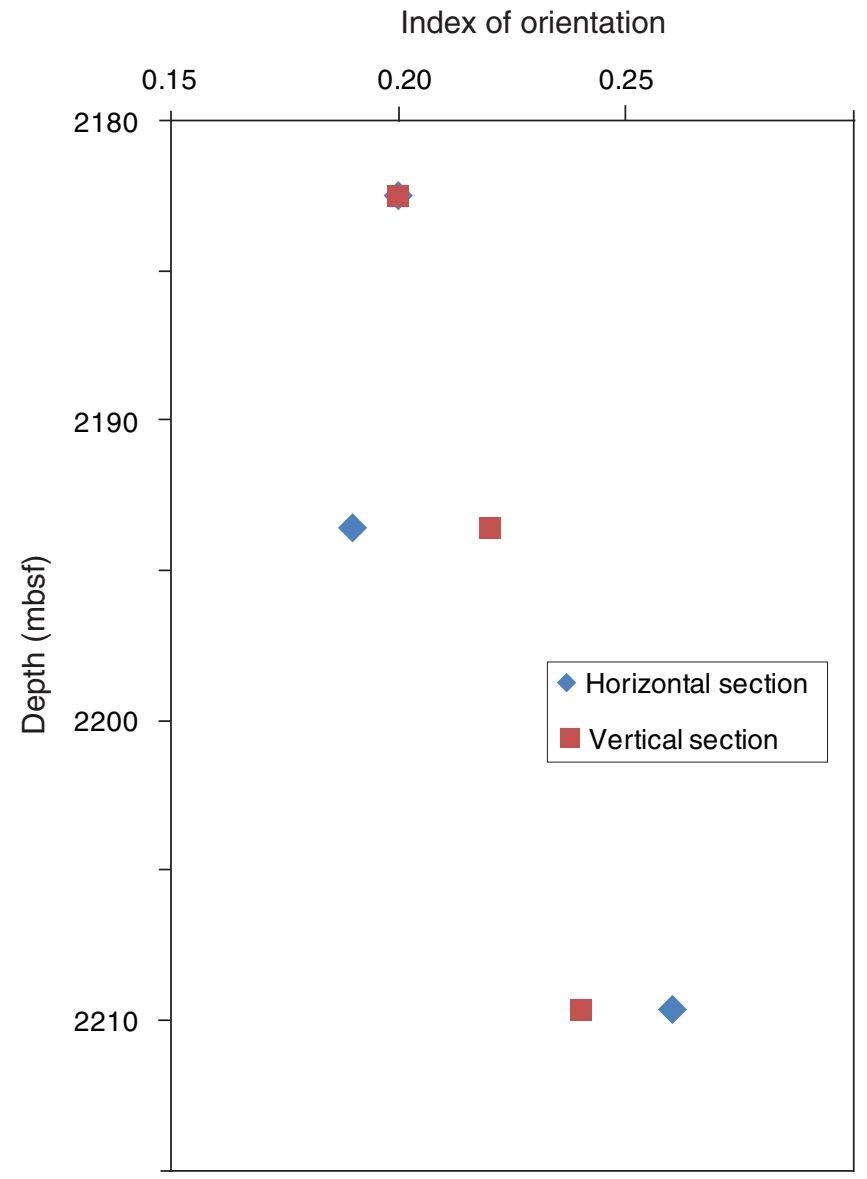


Figure F16. Vertical intrinsic permeability for mud and mudstone specimens from NanTroSEIZE Nankai Trough transect (Fig. F1) and Muroto transect, ODP Leg 190 (Gamage et al., 2011). Sources of NanTroSEIZE data include Rowe et al. (2011), Saffer et al. (2011), Guo et al. (2011), Dugan and Daigle (2011), Ekinici et al. (2011), Yue et al. (2012), Screaton et al. (2013), Dugan and Zhao (2013), Hüpers and Kopf (2012), Guo and Underwood (2014), Daigle and Dugan (2014). Circled symbols highlight deeper core specimens from Hole C0002P (this study).

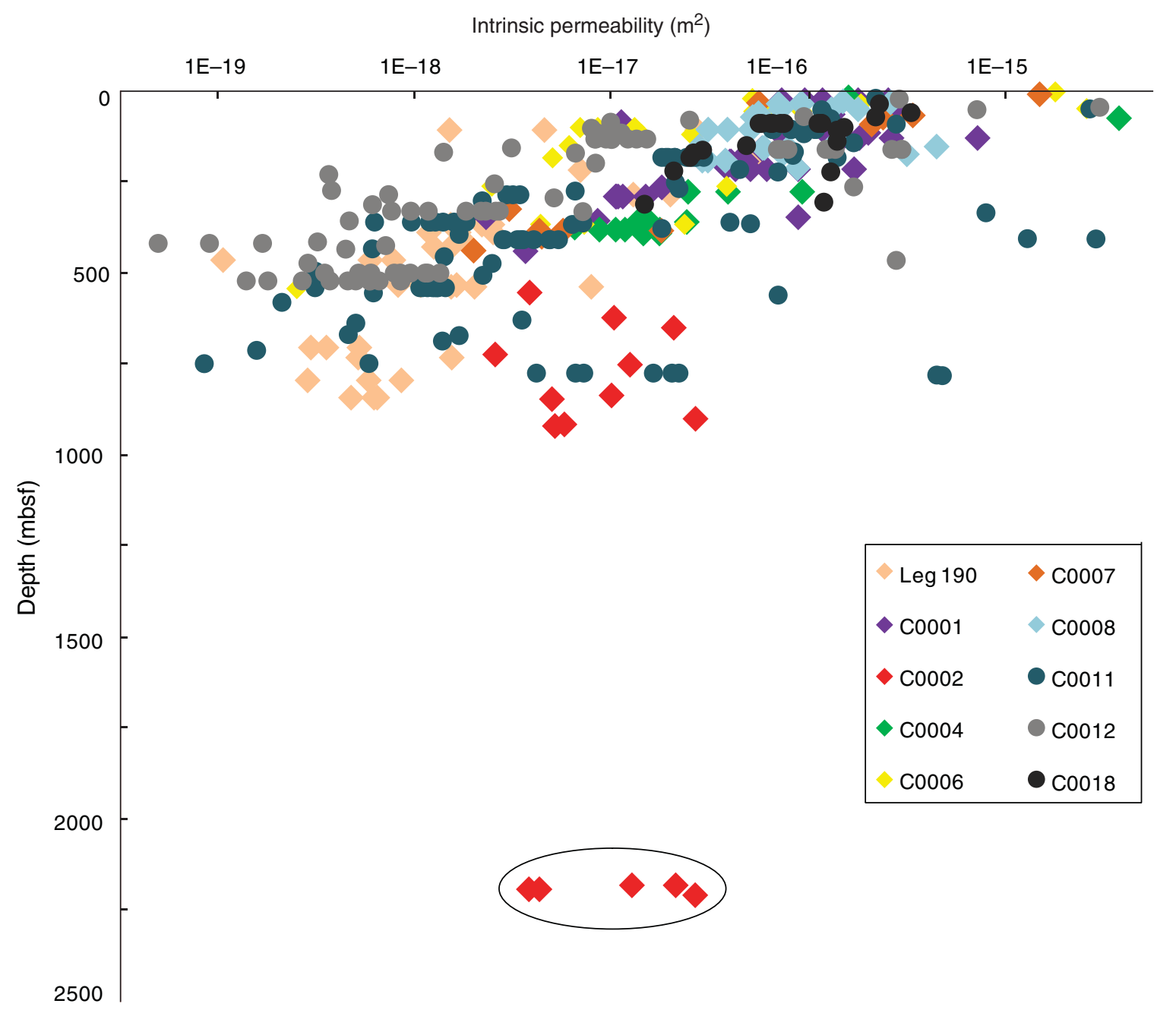


Figure F17. Relation between intrinsic permeability and post-test porosity for specimens from different subduction zones. See Figure F16 for sources of data. Circled symbols highlight deeper core specimens from Hole C0002P (this study).

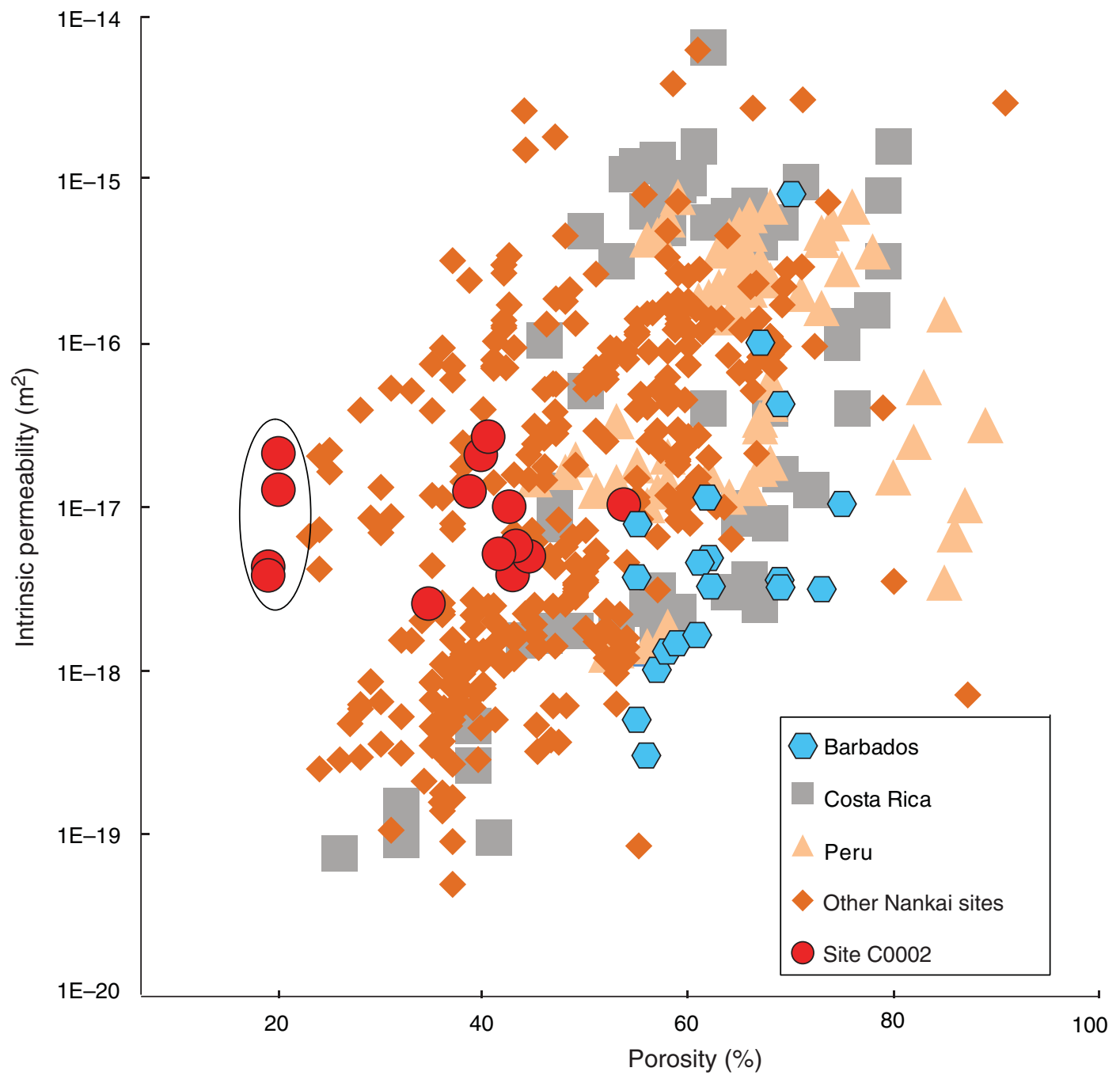


Table T1. Summary of lithologic Unit V specimen properties before and after flow-through permeability tests, Hole C0002P.

\begin{tabular}{|c|c|c|c|c|c|c|c|c|c|c|c|c|}
\hline \multirow[b]{2}{*}{$\begin{array}{l}\text { Core, section, } \\
\text { interval }(\mathrm{cm})\end{array}$} & \multirow[b]{2}{*}{$\begin{array}{l}\text { Top depth } \\
\text { (mbsf) }\end{array}$} & \multirow[b]{2}{*}{$\begin{array}{l}\text { Bedding } \\
\operatorname{dip}\left({ }^{\circ}\right)\end{array}$} & \multirow[b]{2}{*}{$\begin{array}{l}\text { Cylinder } \\
\text { orientation }\end{array}$} & \multirow[b]{2}{*}{$\begin{array}{c}\text { Average } \\
\text { height } \\
(\mathrm{cm})\end{array}$} & \multirow[b]{2}{*}{$\begin{array}{c}\text { Aveerage } \\
\text { diameter } \\
(\mathrm{cm})\end{array}$} & \multirow[b]{2}{*}{$\begin{array}{l}\text { Skempton } \\
\text { B-value }\end{array}$} & \multicolumn{2}{|c|}{ Shipboard data } & \multicolumn{2}{|c|}{ Before test } & \multicolumn{2}{|c|}{ After test } \\
\hline & & & & & & & $\begin{array}{c}\text { Grain } \\
\text { density } \\
\left(\mathrm{g} / \mathrm{cm}^{3}\right)\end{array}$ & $\begin{array}{l}\text { Porosity } \\
\text { (\%) }\end{array}$ & $\begin{array}{l}\text { Water } \\
\text { content } \\
(\%)\end{array}$ & $\begin{array}{l}\text { Porosity } \\
\text { (\%) }\end{array}$ & $\begin{array}{l}\text { Water } \\
\text { content } \\
(\%)\end{array}$ & $\begin{array}{l}\text { Porosity } \\
\text { (\%) }\end{array}$ \\
\hline \multicolumn{13}{|l|}{ 348-C0002P- } \\
\hline 2R-2, 107-114 & 2174.98 & 83 & Trim failed & & & & 2.745 & 18.9 & & & & \\
\hline $3 R-1,51-72$ & 2182.51 & 88 & Vertical & 7.80 & 3.80 & 0.82 & 2.743 & 19.6 & 11.5 & 24 & 9.1 & 20 \\
\hline $4 \mathrm{R}-2,98-103$ & 2193.58 & 89 & Vertical & 3.65 & 4.15 & 0.84 & 2.715 & 20.8 & 5.1 & 12 & 8.8 & 19 \\
\hline 6R-1, 64-76.5 & 2209.64 & 84 & Vertical & 4.40 & 4.50 & 0.77 & 2.741 & 27.7 & 10.5 & 22 & 9.7 & 21 \\
\hline
\end{tabular}

Table T2. Statistics of preferred orientation of microfabric for core specimens from Hole C0002P calculated from analyses of environmental SEM images.

\begin{tabular}{|c|c|c|c|c|c|c|c|}
\hline \multirow[b]{2}{*}{$\begin{array}{l}\text { Core, section, } \\
\text { interval (cm) }\end{array}$} & \multirow[b]{2}{*}{$\begin{array}{l}\text { Top depth } \\
\text { (mbsf) }\end{array}$} & \multicolumn{3}{|c|}{ Horizontal (perpendicular to core axis) } & \multicolumn{3}{|c|}{ Vertical (parallel to core axis) } \\
\hline & & $\begin{array}{l}\text { Grains } \\
\text { counted }\end{array}$ & $\begin{array}{c}\text { Standard } \\
\text { deviation of } \\
\text { orientation }\left({ }^{\circ}\right)\end{array}$ & $\begin{array}{l}\text { Index of } \\
\text { orientation }\end{array}$ & $\begin{array}{l}\text { Grains } \\
\text { counted }\end{array}$ & $\begin{array}{c}\text { Standard } \\
\text { deviation of } \\
\text { orientation }\left({ }^{\circ}\right)\end{array}$ & $\begin{array}{l}\text { Index of } \\
\text { orientation }\end{array}$ \\
\hline \multicolumn{8}{|l|}{ 348-C0002P- } \\
\hline $3 R-1,51$ & 2182.51 & 645 & 57.5 & 0.20 & 531 & 57.8 & 0.20 \\
\hline $4 \mathrm{R}-2,98$ & 2193.58 & 791 & 58.7 & 0.19 & 841 & 56.3 & 0.22 \\
\hline $6 \mathrm{R}-1,64$ & 2209.64 & 886 & 53.6 & 0.26 & 687 & 54.9 & 0.24 \\
\hline
\end{tabular}

Table T3. Average values of permeability and hydraulic conductivity for specimens from Hole C0002P calculated from test results in the vertical direction, subparallel to bedding.

\begin{tabular}{ccccc}
\hline $\begin{array}{c}\text { Core, section, } \\
\text { interval }(\mathrm{cm})\end{array}$ & $\begin{array}{c}\text { Top depth } \\
(\mathrm{mbsf})\end{array}$ & $\begin{array}{c}\text { Effective stress } \\
(\mathrm{MPa})\end{array}$ & $\begin{array}{c}\text { Hydraulic } \\
\text { conductivity } \\
(\mathrm{cm} / \mathrm{s})\end{array}$ & $\begin{array}{c}\text { Intrinsic } \\
\text { permeability } \\
\left(\mathrm{m}^{2}\right)\end{array}$ \\
\hline 348-C0002P- & & & & \\
3R-1, 51 & 2182.51 & 0.28 & $2.13 \mathrm{E}-08$ & $2.12 \mathrm{E}-17$ \\
3R-1, 51 & 2182.51 & 0.55 & $1.28 \mathrm{E}-08$ & $1.27 \mathrm{E}-17$ \\
4R-2, 98 & 2193.58 & 0.28 & $4.33 \mathrm{E}-09$ & $4.30 \mathrm{E}-18$ \\
4R-2, 98 & 2193.58 & 0.55 & $3.83 \mathrm{E}-09$ & $3.80 \mathrm{E}-18$ \\
6R-1, 64 & 2209.64 & 0.28 & $2.68 \mathrm{E}-08$ & $2.66 \mathrm{E}-17$ \\
\hline
\end{tabular}


Table T4. Results of individual flow-through permeability tests for specimens from Hole C0002P.

\begin{tabular}{|c|c|c|c|c|c|c|c|c|}
\hline $\begin{array}{l}\text { Core, section, } \\
\text { interval }(\mathrm{cm})\end{array}$ & $\begin{array}{l}\text { Effective stress } \\
\quad(\mathrm{MPa})\end{array}$ & Test run & $\begin{array}{l}\text { Volumetric flow } \\
\text { rate }\left(\mathrm{cm}^{3} / \mathrm{min}\right)\end{array}$ & $\begin{array}{c}\text { Discharge } \\
\text { velocity }(\mathrm{cm} / \mathrm{s})\end{array}$ & $\begin{array}{c}\text { Head } \\
\text { difference } \\
(\mathrm{cm})\end{array}$ & $\begin{array}{l}\text { Hydraulic } \\
\text { gradient }\end{array}$ & $\begin{array}{l}\text { Hydraulic } \\
\text { conductivity } \\
(\mathrm{cm} / \mathrm{s})\end{array}$ & $\begin{array}{c}\text { Intrinsic } \\
\text { permeability } \\
\left(\mathrm{m}^{2}\right)\end{array}$ \\
\hline \multicolumn{9}{|l|}{ 348-C0002P- } \\
\hline \multirow[t]{5}{*}{$3 \mathrm{R}-1,51$} & 0.28 & 1 & 0.0002 & $2.94 \mathrm{E}-07$ & 109 & 13.97 & $2.10 \mathrm{E}-08$ & $2.09 \mathrm{E}-17$ \\
\hline & & 2 & -0.0002 & $-2.94 \mathrm{E}-07$ & -107 & -13.72 & $2.14 \mathrm{E}-08$ & $2.13 \mathrm{E}-17$ \\
\hline & & 3 & 0.0004 & $5.88 \mathrm{E}-07$ & 225 & 28.85 & $2.04 \mathrm{E}-08$ & $2.02 \mathrm{E}-17$ \\
\hline & & 4 & -0.0004 & $-5.88 \mathrm{E}-07$ & -204 & -26.15 & $2.25 \mathrm{E}-08$ & $2.23 \mathrm{E}-17$ \\
\hline & & & & & & Average: & $2.13 \mathrm{E}-08$ & $2.12 \mathrm{E}-17$ \\
\hline \multirow[t]{5}{*}{$3 R-1,51$} & 0.55 & 1 & 0.0002 & $2.94 \mathrm{E}-07$ & 184 & 23.59 & $1.25 \mathrm{E}-08$ & $1.24 \mathrm{E}-17$ \\
\hline & & 2 & -0.0002 & $-2.94 \mathrm{E}-07$ & -159 & -20.38 & $1.44 \mathrm{E}-08$ & $1.43 \mathrm{E}-17$ \\
\hline & & 3 & 0.0004 & $5.88 \mathrm{E}-07$ & 377 & 48.33 & $1.22 \mathrm{E}-08$ & $1.21 \mathrm{E}-17$ \\
\hline & & 4 & -0.0004 & $-5.88 \mathrm{E}-07$ & -380 & -48.72 & $1.21 \mathrm{E}-08$ & $1.20 \mathrm{E}-17$ \\
\hline & & & & & & Average: & $1.28 \mathrm{E}-08$ & $1.27 \mathrm{E}-17$ \\
\hline \multirow[t]{5}{*}{$4 \mathrm{R}-2,98$} & 0.28 & 1 & 0.0002 & $2.41 \mathrm{E}-07$ & 200 & 54.05 & 4.45E-09 & 4. $42 \mathrm{E}-18$ \\
\hline & & 2 & -0.0002 & $-2.41 \mathrm{E}-07$ & -247 & -66.76 & $3.60 \mathrm{E}-09$ & $3.58 \mathrm{E}-18$ \\
\hline & & 3 & 0.0004 & $4.81 \mathrm{E}-07$ & 358 & 96.76 & 4.97E-09 & $4.94 \mathrm{E}-18$ \\
\hline & & 4 & -0.0004 & $-4.81 E-07$ & -414 & -111.89 & $4.30 \mathrm{E}-09$ & $4.27 \mathrm{E}-18$ \\
\hline & & & & & & Average: & $4.33 \mathrm{E}-09$ & $4.30 \mathrm{E}-18$ \\
\hline \multirow[t]{5}{*}{$4 \mathrm{R}-2,98$} & 0.55 & 1 & 0.0002 & $2.53 \mathrm{E}-07$ & 196 & 54.44 & $4.64 \mathrm{E}-09$ & $4.60 \mathrm{E}-18$ \\
\hline & & 2 & -0.0002 & $-2.53 \mathrm{E}-07$ & -288 & -80.00 & $3.16 \mathrm{E}-09$ & $3.13 \mathrm{E}-18$ \\
\hline & & 3 & 0.0004 & $5.05 \mathrm{E}-07$ & 491 & 136.39 & $3.70 \mathrm{E}-09$ & $3.67 \mathrm{E}-18$ \\
\hline & & 4 & -0.0004 & $-5.05 \mathrm{E}-07$ & -475 & -131.94 & $3.83 \mathrm{E}-09$ & $3.80 \mathrm{E}-18$ \\
\hline & & & & & & Average: & $3.83 \mathrm{E}-09$ & $3.80 \mathrm{E}-18$ \\
\hline \multirow[t]{5}{*}{$6 \mathrm{R}-1,64$} & 0.28 & 1 & 0.0006 & $6.34 \mathrm{E}-07$ & 52 & 11.82 & $5.38 \mathrm{E}-08$ & $5.34 \mathrm{E}-17$ \\
\hline & & 2 & -0.0006 & $-6.34 \mathrm{E}-07$ & -183 & -41.59 & $1.53 \mathrm{E}-08$ & $1.52 \mathrm{E}-17$ \\
\hline & & 3 & 0.0008 & $8.45 \mathrm{E}-07$ & 165 & 37.50 & $2.26 \mathrm{E}-08$ & $2.24 \mathrm{E}-17$ \\
\hline & & 4 & -0.0008 & $-8.45 \mathrm{E}-07$ & -238 & -54.09 & $1.57 \mathrm{E}-08$ & $1.55 \mathrm{E}-17$ \\
\hline & & & & & & Average: & $2.68 \mathrm{E}-08$ & $2.66 \mathrm{E}-17$ \\
\hline
\end{tabular}




\section{Appendix}

Figures AF1, AF2, and AF3 are plots of applied discharge velocity and steady-state hydraulic gradient, which allow for visual assessments of consistency and linearity.

Figures AF4, AF5, AF6, AF7, AF8, and AF9 are additional SEM and EDS images used to quantify the differences in grain size and characterize minor compositional constituents (e.g., pyrite) in greater detail. 
Figure AF1. Hydraulic gradient versus discharge velocity for Sample 348-C0002P-3R-1, $51 \mathrm{~cm}$.
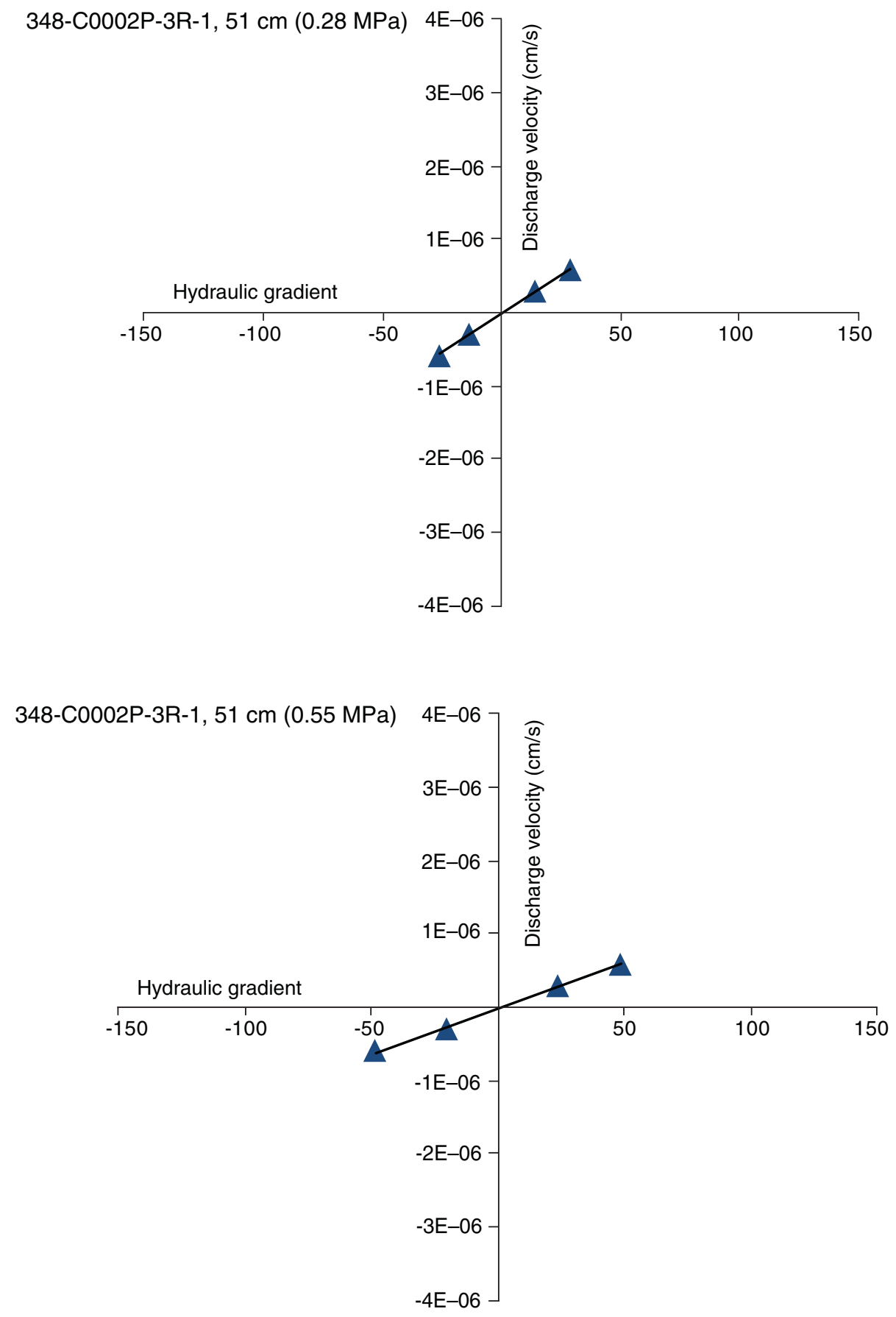
Figure AF2. Hydraulic gradient versus discharge velocity for Sample 348-C0002P-4R-2, 98 cm.
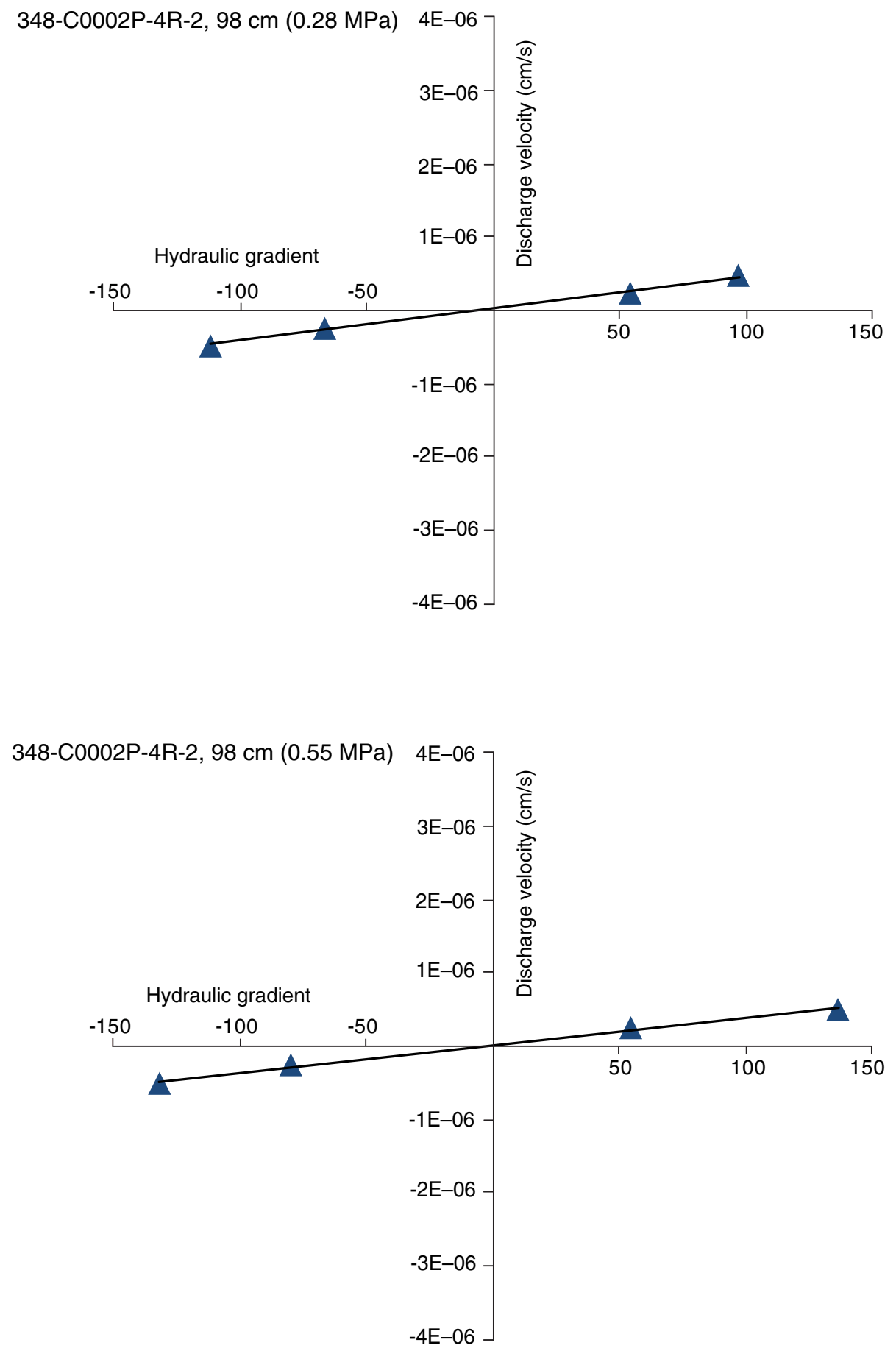
Figure AF3. Hydraulic gradient versus discharge velocity for Sample 348-C0002P-6R-1, 64 cm.

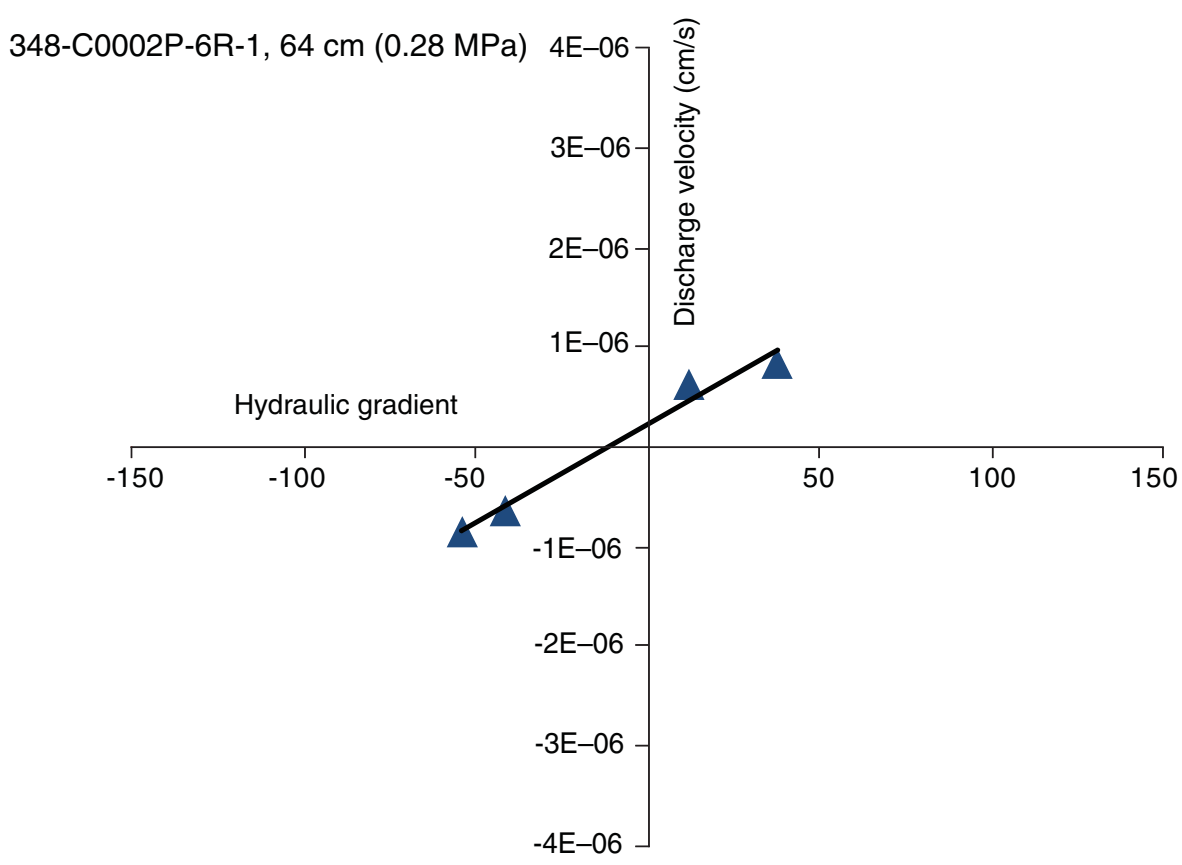


Figure AF4. ESEM images of specimens cut from Sample 348-C0002P-3R-1, $51 \mathrm{~cm}$. A, B. Specimen cut parallel to core axis. C, D. Specimen cut perpendicular to the core axis.

348-C0002P-3R-1, $51 \mathrm{~cm}$

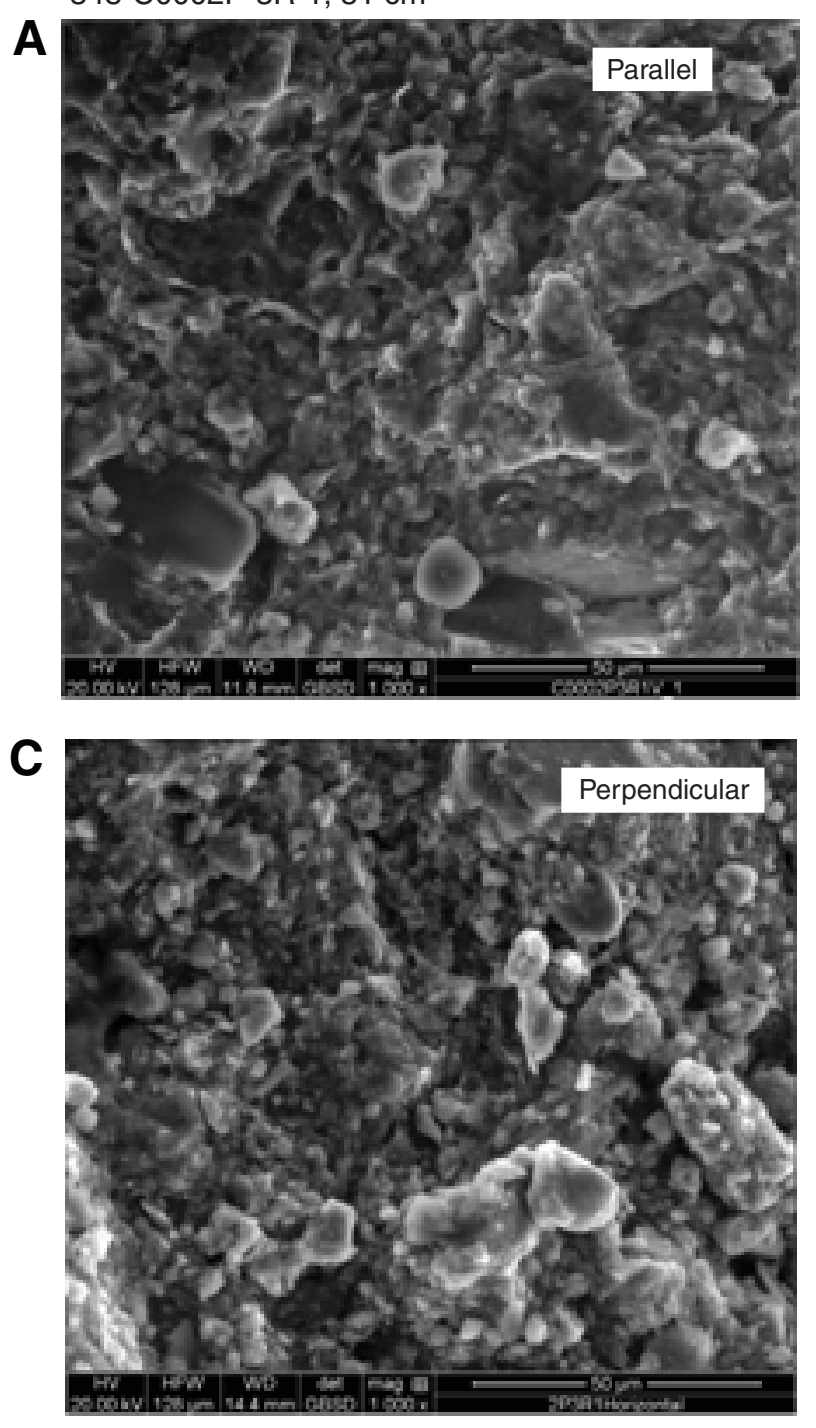

B

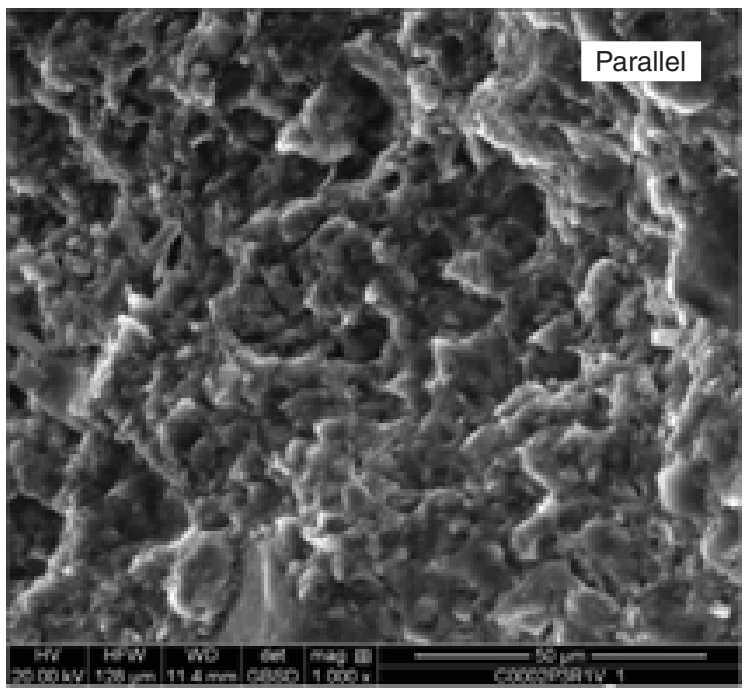

D

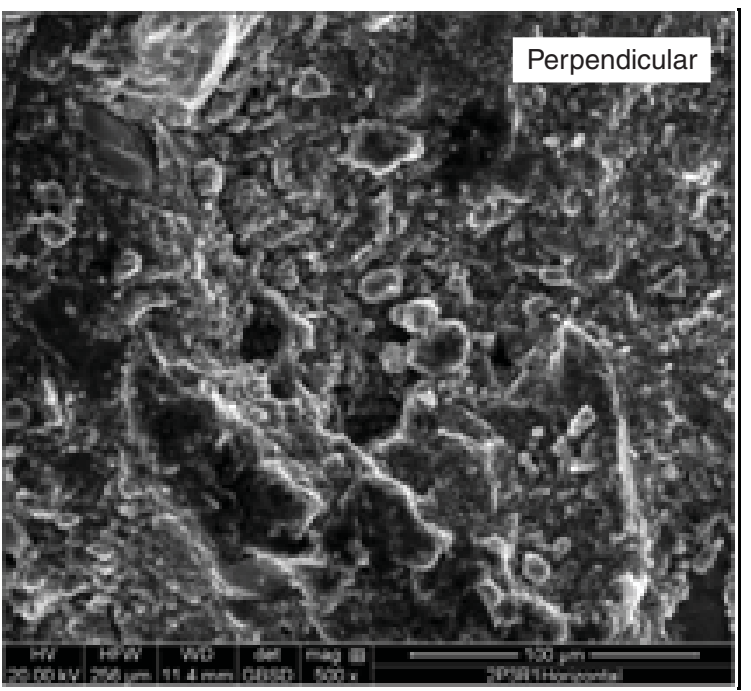


Figure AF5. Documentation of microfossils in a specimen cut from Sample 348-C0002P-3R-1, $51 \mathrm{~cm}$. A. ESEM image used for EDS analysis. B. EDS spectrum of major elements from Point 1 in B. Point 2 yielded similar results. Elemental spectrum is consistent with the composition of calcite $\left(\mathrm{CaCO}_{3}\right)$.

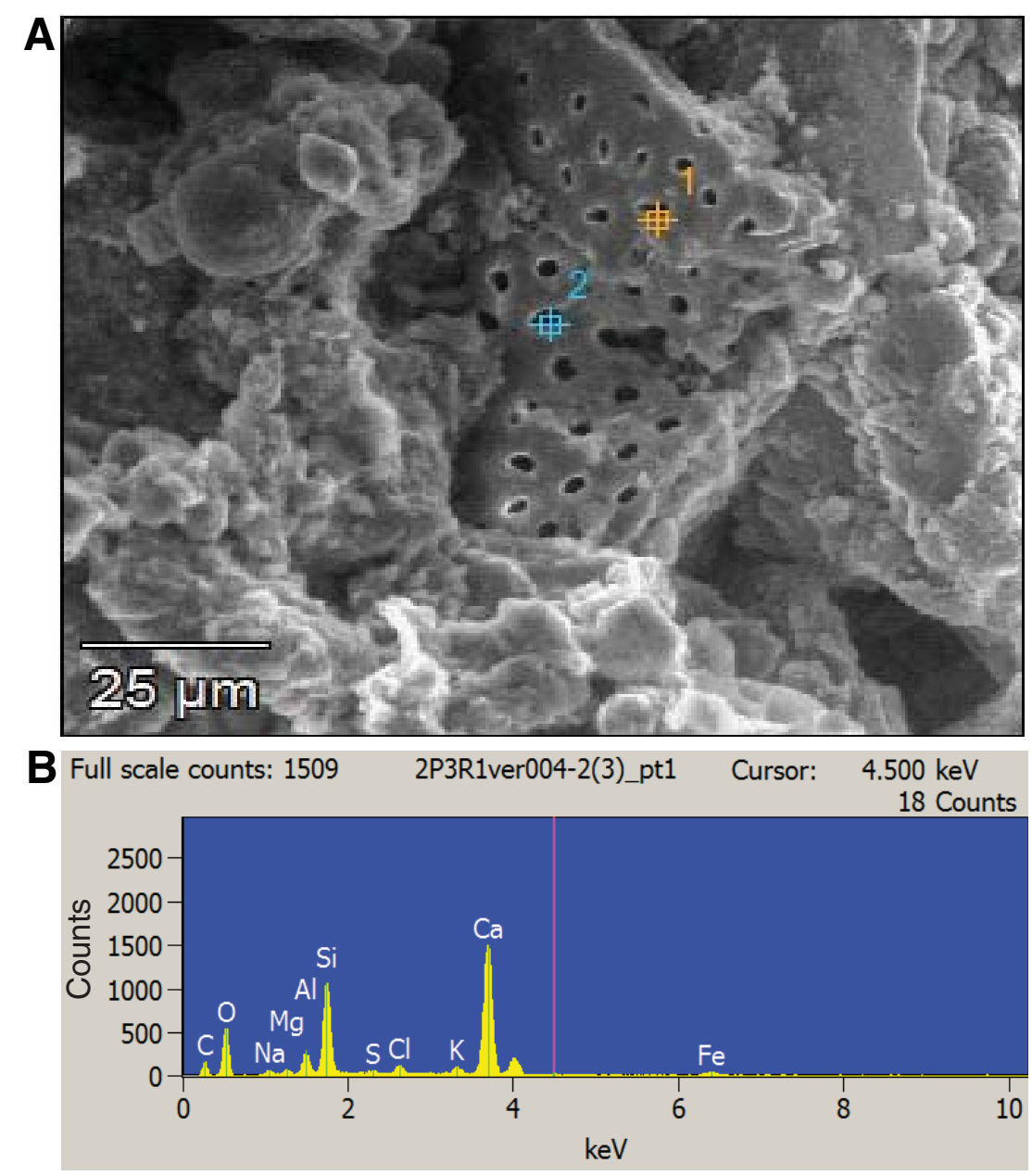


Figure AF6. ESEM images of specimens cut from Sample 348-C0002P-4R-2, $98 \mathrm{~cm}$. A, B. Specimen cut parallel to the core axis. C, D. Specimen cut perpendicular to the core axis.
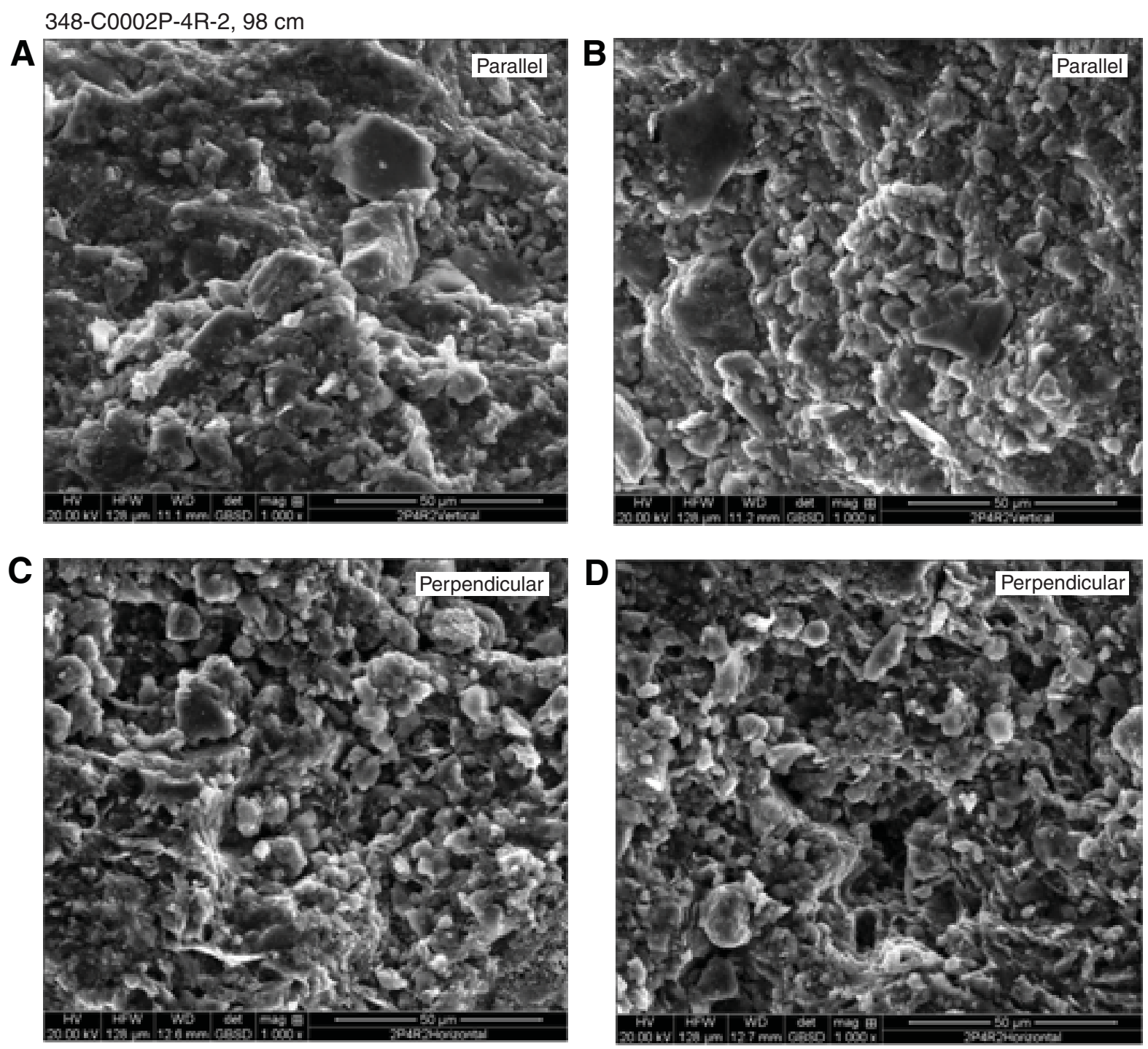
Figure AF7. Documentation of pyrite in the specimen cut from Sample 348-C0002P-4R-2, $98 \mathrm{~cm}$. A. ESEM image used for EDS analysis. B. EDS spectrum of major elements from Point 1 in A. Points 2 and 3 were used for comparison of spectra with typical silicate minerals. Elemental spectrum is consistent with the composition of pyrite $\left(\mathrm{FeS}_{2}\right)$.

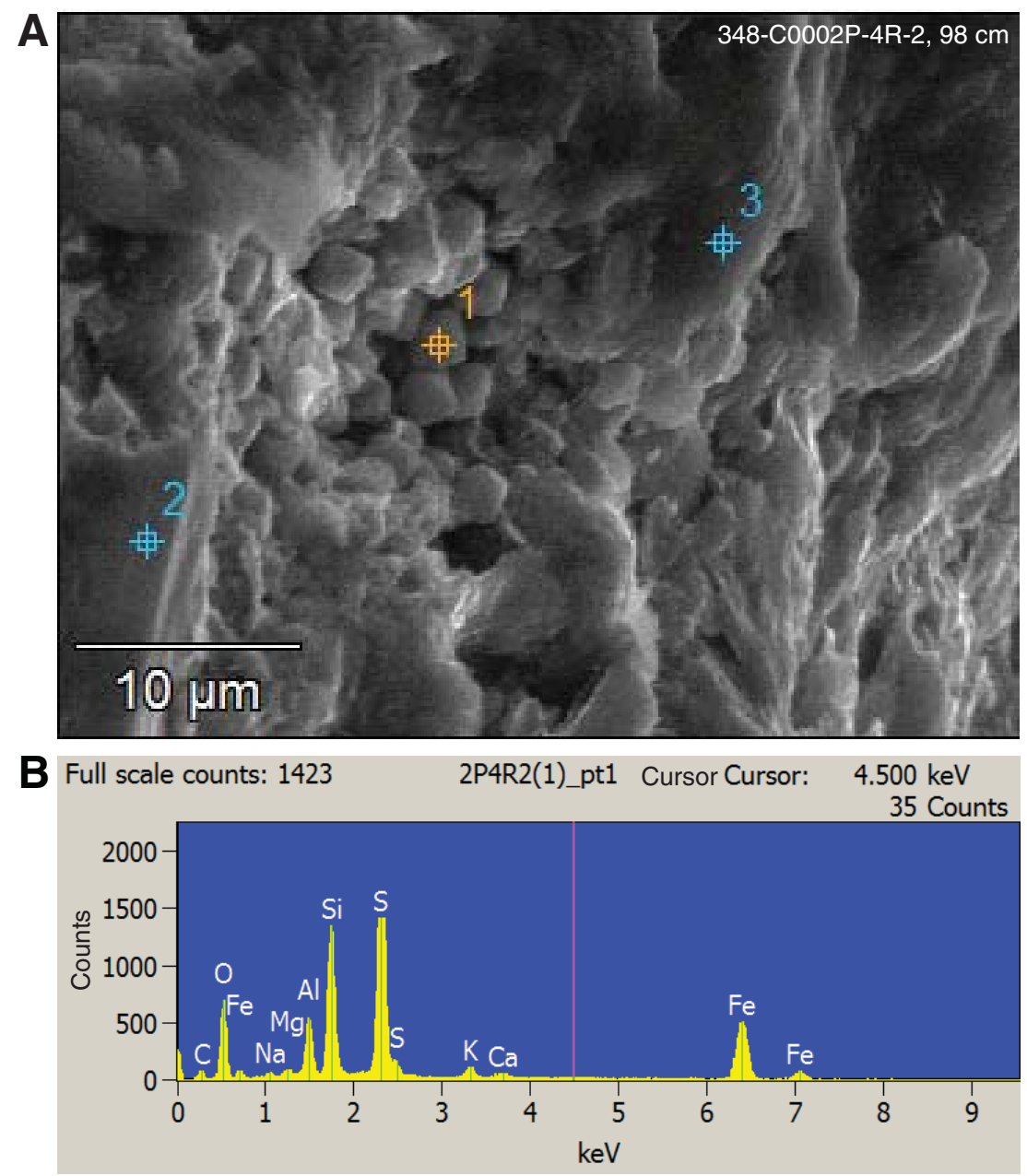


Figure AF8. ESEM images of specimens cut from Sample 348-C0002P-6R-1, $64 \mathrm{~cm}$. A, B. Specimen cut parallel to the core axis. C, D. Specimen cut perpendicular to the core axis.

$348-C 0002 P-6 R-1,64 \mathrm{~cm}$

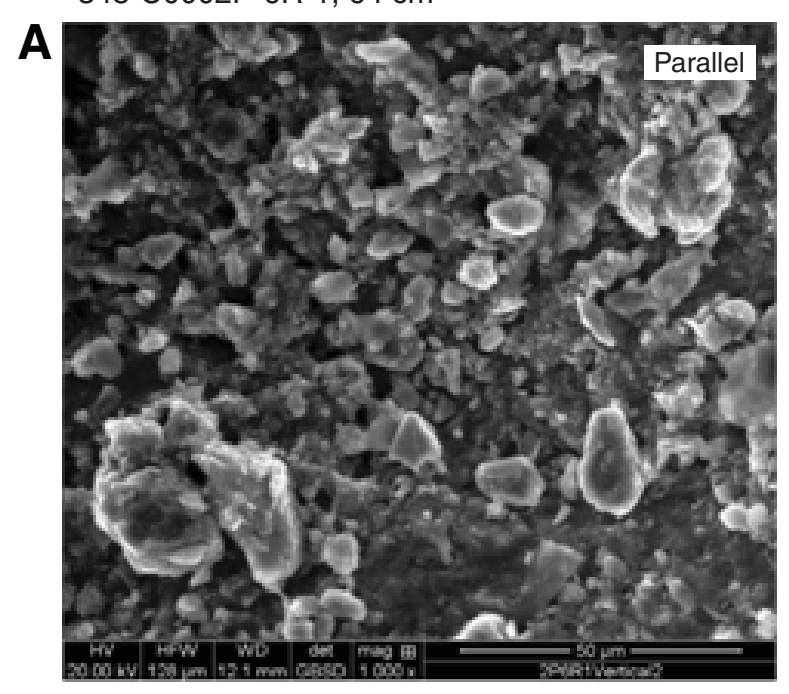

C

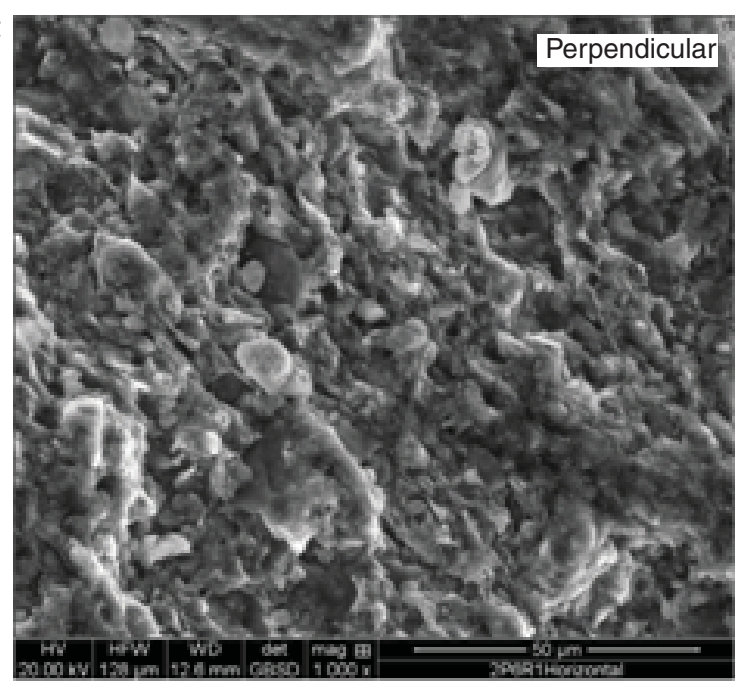

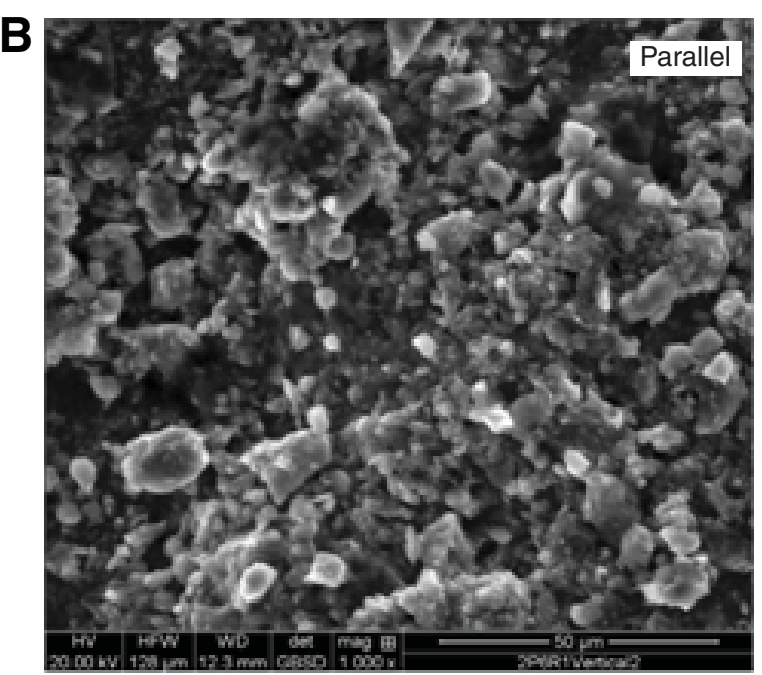

D

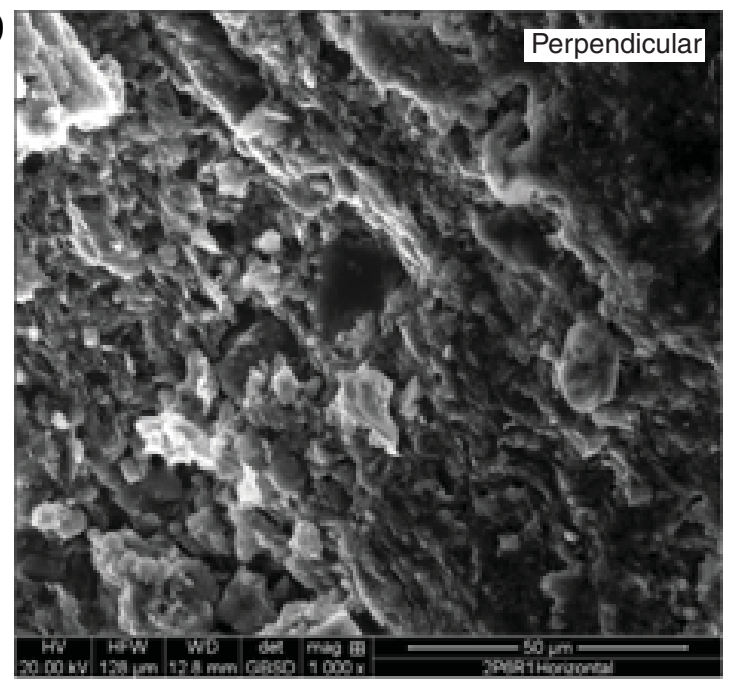


Figure AF9. Documentation of barite the specimen cut from Sample 348-C0002P-6R-1, 64 cm. A, B. ESEM images used for EDS analysis. C. EDS spectrum of major elements from Point 1 in B. Point 1 in A is similar to Point $1 \mathrm{in} \mathrm{B}$. The rest of the points on both images were used for comparison of spectra with typical silicate minerals. Elemental spectrum is consistent with the composition of barite $\left(\mathrm{BaSO}_{4}\right)$.

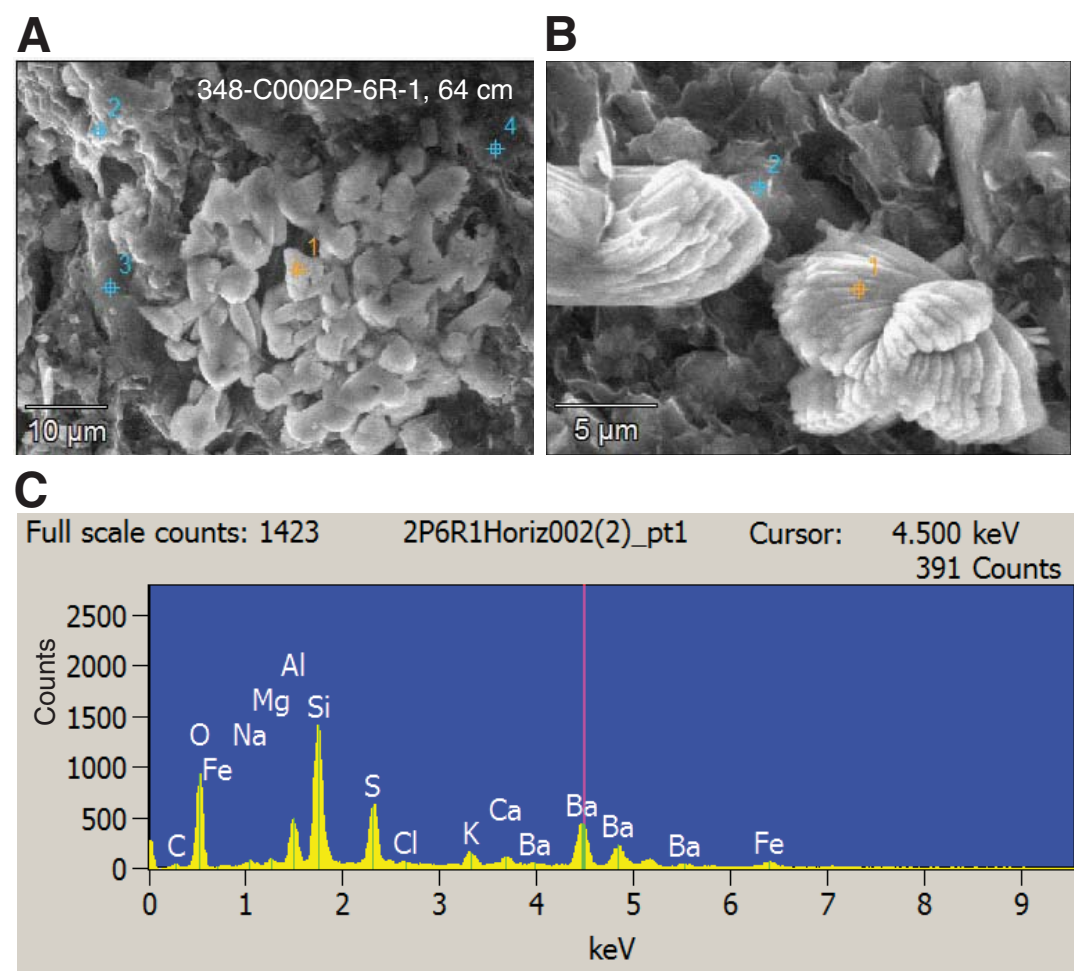

